\title{
A global stratospheric bromine monoxide climatology based on the BASCOE chemical transport model
}

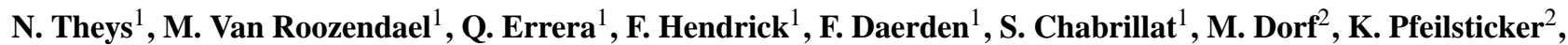

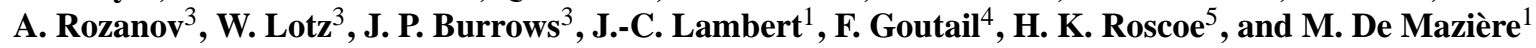 \\ ${ }^{1}$ Belgium Institute for Space Aeronomy (IASB-BIRA), Brussels, Belgium \\ ${ }^{2}$ Institute for Environmental Physics, University of Heidelberg, Heidelberg, Germany \\ ${ }^{3}$ Institute for Environmental Physics, University of Bremen, Bremen, Germany \\ ${ }^{4}$ Service d'Aéronomie, Verrières-le-Buisson, France \\ ${ }^{5}$ British Antarctic Survey, Cambridge, UK
}

Received: 14 July 2008 - Published in Atmos. Chem. Phys. Discuss.: 26 September 2008

Revised: 6 January 2009 - Accepted: 8 January 2009 - Published: 3 February 2009

\begin{abstract}
A new climatology of stratospheric $\mathrm{BrO}$ profiles based on a parameterization using dynamical and chemical indicators has been developed, with the aim to apply it to the retrieval of tropospheric $\mathrm{BrO}$ columns from space nadir measurements. The adopted parameterization is based on three years of output data from the 3-D chemistry transport model BASCOE. The impact of the atmospheric dynamics on the stratospheric $\mathrm{BrO}$ distribution is treated by means of $\mathrm{Br}_{\mathrm{y}} /$ ozone correlations built from 3-D-CTM model results, while photochemical effects are taken into account using stratospheric $\mathrm{NO}_{2}$ columns as an indicator of the $\mathrm{BrO} / \mathrm{Br}_{\mathrm{y}} \mathrm{ra}-$ tio. The model simulations have been optimized for bromine chemistry and budget, and validated through comparisons using an extensive data set of ground-based, balloon-borne and satellite limb (SCIAMACHY) stratospheric BrO observations.
\end{abstract}

\section{Introduction}

Inorganic bromine $\left(\mathrm{Br}_{\mathrm{y}}=\mathrm{Br}+\mathrm{BrO}+\mathrm{BrONO}_{2}+\mathrm{HOBr}+\mathrm{HBr}+\right.$ $\mathrm{BrCl}+2 \mathrm{Br}_{2}$ ) plays an important role in the stratosphere, as it is known to cause significant ozone destruction. Bromine monoxide $(\mathrm{BrO})$ can significantly influence the chemical composition of the stratosphere and contribute to ozone depletion through catalytic reactions with $\mathrm{NO}_{2}, \mathrm{ClO}, \mathrm{HO}_{2}$ and $\mathrm{O}$ (Lary, 1996). Although inorganic bromine is present in the

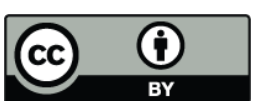

Correspondence to: $\mathrm{N}$. Theys (theys@aeronomie.be) stratosphere in small quantities relative to chlorine, its large ozone depletion efficiency makes stratospheric bromine contribute to mid-latitude ozone loss by about $25 \%$ and to polar ozone depletion, mainly through the $\mathrm{BrO} / \mathrm{ClO}$ cycle (McElroy et al., 1986), up to $50 \%$.

The origin of stratospheric inorganic bromine is both natural and anthropogenic. The major contribution to the stratospheric inorganic bromine budget comes from long-lived bromine-containing organic source gases, transported from the Earth's surface to the stratosphere, where they are converted into inorganic forms. The long-lived organic bromine species currently contribute to the stratospheric $\mathrm{Br}_{\mathrm{y}}$ loading by about 16-17 pptv (Montzka et al., 2003). This estimate is based on a budget of observations of the main long-lived organic bromine source gases $\left(\mathrm{CH}_{3} \mathrm{Br}, \mathrm{CBrClF}_{2}\right.$, $\left.\mathrm{CBrF}_{3}, \mathrm{CBrF}_{2} \mathrm{CBrF}_{2}\right)$. However, several recent studies based on measurements of stratospheric $\mathrm{BrO}$ using remote-sensing UV-visible techniques from ground-based (Sinnhuber et al., 2002; Schofield et al., 2004 and 2006; Hendrick et al., 2007; Theys et al., 2007), balloon-borne (Pundt et al., 2002; Salawitch et al., 2005; Dorf et al., 2006a, b and 2008) and space-borne limb (Sinnhuber et al., 2005; Sioris et al., 2006) instruments have inferred a total inorganic bromine loading of 18-25 pptv, suggesting that an additional contribution must be considered, possibly due to bromine release from short-lived biogenic organic compounds (such as $\mathrm{CHBr}_{3}$, $\mathrm{CH}_{2} \mathrm{Br}_{2}, \mathrm{CH}_{2} \mathrm{BrCl}, \mathrm{CHBr}_{2} \mathrm{Cl}, \mathrm{CHBrCl}_{2}, \mathrm{CH}_{2} \mathrm{BrCH}_{2} \mathrm{Br}$ ) or even through direct injection of inorganic bromine from tropospheric origin into the lower stratosphere (WMO, 2007). Enhanced $\mathrm{Br}_{\mathrm{y}}$ due to very short-lived species (VSLS) can

Published by Copernicus Publications on behalf of the European Geosciences Union. 
affect the ozone loss and chemical composition in the lower stratosphere and substantially influence ozone trend simulations (e.g. Salawitch et al., 2005; Feng et al., 2007).

Inorganic bromine compounds can also be present in the free-troposphere due to the decomposition of $\mathrm{CH}_{3} \mathrm{Br}$ and VSLS bromine compounds. This is supported by observations from space (Wagner and Platt, 1998; Richter et al., 2002; Van Roozendael et al., 2002), the ground (Hendrick et al., 2007; Theys et al., 2007) and balloon (Harder et al., 1998; Fitzenberger et al., 2000). Based on the observational estimates of bromine monoxide in the free-troposphere, modelling results (von Glasow et al., 2004; Lary, 2005; Yang et al., 2005) have shown that bromine might have a significant impact on tropospheric ozone (and on tropospheric chemistry in general), leading to a reduction in the $\mathrm{O}_{3}$ mixing ratio of up to $40 \%$ locally. Further down in the boundary layer, inorganic bromine compounds have been shown to be responsible for complete ozone depletion events (ODEs) in the polar regions, during the so-called polar spring bromine explosion event (Hausmann and Platt, 1994; Kreher et al., 1997; Hönninger and Platt, 2002; Frieß et al., 2004; Simpson et al., 2007). Although in smaller quantities, tropospheric $\mathrm{BrO}$ emissions have also been identified over salt lakes (Hebestreit et al., 1999), as well as in the marine boundary layer (Leser et al., 2003) and in volcanic plumes (Bobrowski et al., 2003).

Satellite UV-visible nadir instruments (such as GOME/ERS-2, SCIAMACHY/ENVISAT and GOME2/MetOp-1) offer the unique capability to study and monitor $\mathrm{BrO}$ at the global scale (Chance, 1998; Richter et al., 2002; Van Roozendael et al., 2002; Wagner et al., 1998). However, to quantitatively investigate and characterize the spatial and seasonal variations of tropospheric $\mathrm{BrO}$, the measured total $\mathrm{BrO}$ vertical column densities (VCDs) must be resolved into their stratospheric and tropospheric contributions.

Here, we report on the development of a stratospheric $\mathrm{BrO}$ profile climatology designed for use in the retrieval of global tropospheric $\mathrm{BrO}$ VCDs from space-borne nadir observations. A new method for the estimation of the stratospheric $\mathrm{BrO}$ content is proposed, which is able to reproduce the important spatial and temporal variations of stratospheric $\mathrm{BrO}$ by using dynamical and chemical indicators. In practice, the climatology uses measured quantities to evaluate stratospheric $\mathrm{BrO}$, which makes the approach well suited for satellite nadir retrieval since it guarantees that the sounded air masses and geophysical conditions are optimally represented. In Sect. 2, we briefly review the 3-D chemical transport model (CTM) which is at the heart of our study. We describe the set-up of bromine species implemented in the model, in the light of our current understanding of stratospheric bromine photochemistry and budget. The treatment of sulphate aerosols in the model is also presented, since it can have a substantial impact on the stratospheric chemistry. Comparisons between modelled results and correlative observations of $\mathrm{O}_{3}, \mathrm{NO}_{2}$ and $\mathrm{BrO}$ are shown in Sect. 3. The stratospheric $\mathrm{BrO}$ profile (and corresponding column) climatology is developed and presented in Sect. 4, together with an error analysis. Conclusions are given in Sect. 5.

\section{Model}

The model used is the stratospheric 3-dimensional chemical transport model which forms the core of BASCOE, a 4dimensional variational (4-D-Var) chemical data assimilation system designed for the analysis and forecast of stratospheric ozone and chemical species (see http://bascoe.oma.be). The CTM is described in Errera and Fonteyn (2001), Daerden et al. (2007) and Errera et al. (2008). It includes a full description of stratospheric chemistry based on 57 chemical species and a parameterization of the microphysics of polar stratospheric clouds (PSCs). All chemical species are advected and interact through 144 gas-phase reactions, 48 photolysis reactions and 9 heterogeneous reactions, all listed in the Jet Propulsion Laboratory (JPL) compilation evaluation 14 (Sander et al., 2003). The CTM is driven by the European Centre for Medium-Range Weather Forecasts (ECMWF) operational analysis of temperatures and winds. The model is defined on 37 pressure levels from the surface to $0.1 \mathrm{hPa}$, on a $3.75^{\circ}$ latitude and $5^{\circ}$ longitude grid, with a model time step of 30 minutes. While the model extends down to the surface, it does not include any tropospheric process and is not expect to produce a realistic chemical composition below the tropopause.

The data used in this study result from a CTM run (no assimilation) initialized with analysis of MIPAS assimilation (details can be found in Errera et al., 2008). The simulations start on 1st April 2003 and end on 31st March 2006, covering three years of data.

\subsection{Bromine species}

The BASCOE 3-D CTM includes a detailed bromine chemistry scheme involving the photochemical reactions listed in Table 1. Inorganic bromine species interact through 30 gasphase and heterogeneous photochemical reactions. Simulations include the reaction of $\mathrm{BrONO}_{2}+\mathrm{O}\left({ }^{3} \mathrm{P}\right) \rightarrow \mathrm{BrO}+\mathrm{NO}_{3}$, since several studies (Soller et al., 2001; Sinnhuber et al., 2002) found that this reaction can lead to increasing daytime $\mathrm{BrO}$ amount above $25 \mathrm{~km}$, especially at low latitudes. Updated kinetic and photochemical data for bromine species are taken from the JPL compilation evaluation 15 (Sander et al., 2006). Sensitivity tests have been made to estimate the impact on the simulated $\mathrm{BrO}$ fields of the incomplete (i.e. limited to bromine reactions) porting of the BASCOE chemical scheme to JPL evaluation 15 chemical kinetics and photochemical data. Differences in the $\mathrm{BrO}$ concentrations were found to be lower than $7 \%$, with respect to a complete update of the full chemistry. This source of error is considered as being rather small compared to the $\mathrm{BrO}$ observational error (see Sect. 3.2). 
Table 1. Bromine reactions included in the BASCOE model.

\begin{tabular}{|c|c|c|c|}
\hline No & Reaction & No & Reaction \\
\hline (R1) & $\mathrm{BrO}+\mathrm{NO}_{2}+\mathrm{M} \rightarrow \mathrm{BrONO}_{2}+\mathrm{M}$ & $(\mathrm{R} 21)$ & $\mathrm{BrONO}_{2}+\mathrm{O} \rightarrow \mathrm{BrO}+\mathrm{NO}_{3}$ \\
\hline (R2) & $\mathrm{BrO}+\mathrm{HO}_{2} \rightarrow \mathrm{HOBr}+\mathrm{O}_{2}$ & $(\mathrm{R} 22)$ & $\mathrm{BrONO}_{2}+\mathrm{HCl} \stackrel{\mathrm{Het}}{\longrightarrow} \mathrm{BrCl}+\mathrm{HNO}_{3}$ \\
\hline (R3) & $\mathrm{BrONO}_{2}+\mathrm{H}_{2} \mathrm{O} \stackrel{\mathrm{Het}}{\longrightarrow} \mathrm{HOBr}+\mathrm{HNO}_{3}$ & (R23) & $\mathrm{HOBr}+\mathrm{HCl} \stackrel{\mathrm{Het}}{\longrightarrow} \mathrm{BrCl}+\mathrm{H}_{2} \mathrm{O}$ \\
\hline (R4) & $\mathrm{BrO}+\mathrm{NO} \rightarrow \mathrm{Br}+\mathrm{NO}_{2}$ & (R24) & $\mathrm{HOBr}+\mathrm{HBr} \stackrel{\mathrm{Het}}{\longrightarrow} \mathrm{Br}_{2}+\mathrm{H}_{2} \mathrm{O}$ \\
\hline (R5) & $\mathrm{BrO}+\mathrm{O} \rightarrow \mathrm{Br}+\mathrm{O}_{2}$ & (R25) & $\mathrm{BrONO}_{2}+\mathrm{h} v \rightarrow \mathrm{BrO}+\mathrm{NO}_{2}$ \\
\hline (R6) & $\mathrm{BrO}+\mathrm{OH} \rightarrow \mathrm{HO}_{2}+\mathrm{Br}$ & (R26) & $\mathrm{BrONO}_{2}+\mathrm{h} v \rightarrow \mathrm{Br}+\mathrm{NO}_{3}$ \\
\hline (R7) & $\mathrm{BrO}+\mathrm{ClO} \rightarrow \mathrm{Br}+\mathrm{OClO}$ & (R27) & $\mathrm{HOBr}+\mathrm{h} v \rightarrow \mathrm{Br}+\mathrm{OH}$ \\
\hline (R8) & $\mathrm{BrO}+\mathrm{ClO} \rightarrow \mathrm{Br}+\mathrm{ClOO}$ & (R28) & $\mathrm{BrCl}+\mathrm{h} v \rightarrow \mathrm{Br}+\mathrm{Cl}$ \\
\hline (R9) & $\mathrm{BrO}+\mathrm{ClO} \rightarrow \mathrm{BrCl}+\mathrm{O}_{2}$ & (R29) & $\mathrm{BrO}+\mathrm{h} v \rightarrow \mathrm{Br}+\mathrm{O}$ \\
\hline (R10) & $\mathrm{BrO}+\mathrm{BrO} \rightarrow 2 \mathrm{Br}+\mathrm{O}_{2}$ & (R30) & $\mathrm{Br}_{2}+\mathrm{h} v \rightarrow 2 \mathrm{Br}$ \\
\hline (R11) & $\mathrm{BrO}+\mathrm{BrO} \rightarrow \mathrm{Br}_{2}+\mathrm{O}_{2}$ & (R31) & $\mathrm{CH}_{3} \mathrm{Br}+\mathrm{h} v \rightarrow \mathrm{Br}+\mathrm{CH}_{3}$ \\
\hline (R12) & $\mathrm{Br}+\mathrm{OClO} \rightarrow \mathrm{BrO}+\mathrm{ClO}$ & (R32) & $\mathrm{CH}_{3} \mathrm{Br}+\mathrm{O}\left({ }^{1} \mathrm{D}\right) \rightarrow \mathrm{Br}+$ products \\
\hline (R13) & $\mathrm{Br}+\mathrm{HO}_{2} \rightarrow \mathrm{HBr}+\mathrm{O}_{2}$ & (R33) & $\mathrm{CH}_{3} \mathrm{Br}+\mathrm{OH} \rightarrow \mathrm{Br}+\mathrm{H}_{2} \mathrm{O}+$ products \\
\hline (R14) & $\mathrm{Br}+\mathrm{CH}_{2} \mathrm{O} \rightarrow \mathrm{HBr}+\mathrm{HCO}$ & (R34) & $\mathrm{CBrClF}_{2}+\mathrm{h} v \rightarrow \mathrm{Br}+\mathrm{Cl}+$ products \\
\hline (R15) & $\mathrm{Br}+\mathrm{O}_{3} \rightarrow \mathrm{BrO}+\mathrm{O}_{2}$ & (R35) & $\mathrm{CBrClF}_{2}+\mathrm{O}\left({ }^{1} \mathrm{D}\right) \rightarrow \mathrm{Br}+\mathrm{Cl}+$ products \\
\hline (R16) & $\mathrm{Br}_{2}+\mathrm{OH} \rightarrow \mathrm{HOBr}+\mathrm{Br}$ & (R36) & $\mathrm{CBrF}_{3}+\mathrm{h} v \rightarrow \mathrm{Br}+$ products \\
\hline (R17) & $\mathrm{HOBr}+\mathrm{O} \rightarrow \mathrm{BrO}+\mathrm{OH}$ & (R37) & $\mathrm{CBrF}_{3}+\mathrm{O}\left({ }^{1} \mathrm{D}\right) \rightarrow \mathrm{Br}+$ products \\
\hline (R18) & $\mathrm{HBr}+\mathrm{O} \rightarrow \mathrm{Br}+\mathrm{OH}$ & (R38) & $\mathrm{CH}_{2} \mathrm{Br}_{2}+\mathrm{h} v \rightarrow 2 \mathrm{Br}+$ products \\
\hline (R19) & $\mathrm{HBr}+\mathrm{OH} \rightarrow \mathrm{Br}+\mathrm{H}_{2} \mathrm{O}$ & (R39) & $\mathrm{CH}_{2} \mathrm{Br}_{2}+\mathrm{OH} \rightarrow 2 \mathrm{Br}+$ products \\
\hline (R20) & $\mathrm{HBr}+\mathrm{O}\left({ }^{1} \mathrm{D}\right) \rightarrow \mathrm{Br}+\mathrm{OH}$ & & \\
\hline
\end{tabular}

Our calculations assume a total inorganic bromine loading in the stratosphere of 23 pptv, in accordance with published results (Pfeilsticker et al., 2000; Salawitch et al., 2006; Hendrick et al., 2007 and 2008a; Theys et al., 2007). The model includes the main tropospheric long-lived (LL) organic bromine sources: methyl bromide $\left(\mathrm{CH}_{3} \mathrm{Br}\right)$, Halon$1211\left(\mathrm{CBrClF}_{2}\right)$ and Halon-1301 $\left(\mathrm{CBrF}_{3}\right)$. The volume mixing ratios (VMRs) have been scaled and made consistent with surface values measured in 1999 by Montzka et al. (2003); i.e. $\mathrm{CH}_{3} \mathrm{Br}$ : 9.5 pptv, Halon-1211: 4.0 pptv and Halon-1301: 3.5 pptv (a constant 1 pptv of Br from Halon-2402 has been added to the measured 2.5 pptv of Halon-1301). The full conversion of LL organic bromine compounds into inorganic forms (occurring above $\sim 25 \mathrm{~km}$ ) leads to a stratospheric $\mathrm{Br}_{\mathrm{y}}$ loading of 17 pptv, for air of 4-5 years mean age. To account for the bromine release from very short-lived species, an additional contribution of $6 \mathrm{pptv}$ has been considered, consisting of 5 pptv of $\mathrm{Br}_{\mathrm{y}}$ from dibromomethane $\left(\mathrm{CH}_{2} \mathrm{Br}_{2}\right)$ and 1 pptv of tropospheric inorganic product gas directly injected at the tropopause. This method of implementing the shortlived bromine species is similar to what has been used in Feng et al. (2007).

A loss process of $\mathrm{Br}_{\mathrm{y}}$ in the troposphere through washout due to the high solubility of $\mathrm{HBr}$, has been implemented and is described by a washout time $\tau$. This washout time is assumed to be constant throughout the troposphere and is fixed at 15 days. Model calculations often use a mean washout time $\tau$ of about 10 to 30 days (e.g. von Glasow et al., 2004; Sinnhuber and Folkins, 2006).

\subsection{Stratospheric aerosol settings}

Particular attention has been paid to the treatment of the stratospheric sulphate aerosols and their impact on stratospheric bromine chemistry. The heterogeneous reactions on the surface of stratospheric aerosols can significantly influence the $\mathrm{BrO} / \mathrm{Br}_{\mathrm{y}}$ partitioning through its impact on the $\mathrm{NO}_{\mathrm{x}} / \mathrm{NO}_{\mathrm{y}}$ ratio or directly through the heterogeneous reactions involving inorganic bromine species (Lary et al., 1996).

In the present work, an improved set-up of stratospheric aerosols has been implemented, derived from that used in Daerden et al. (2007). The aerosol surface area density is calculated based on the aerosol size distribution, which is assumed to follow a log-normal shape defined by the so-called RNS parameters (R: mean radius, $\mathrm{N}$ : total number density, $\mathrm{S}$ : standard deviation). The BASCOE aerosol configuration relies on a composite profile climatology of RNS parameter estimates for each month of the year and for 19 zonal bands. The RNS parameters have been estimated such that the corresponding $1 \mu \mathrm{m}$ aerosol extinction is consistent with SAGE-II extinction from Bingen et al. (2004) for latitudes between $\pm 60^{\circ}$ and with POAM III extinction from Fromm et al. (2003) for regions poleward of $\pm 60^{\circ}$. Adopting this approach for the treatment of stratospheric aerosols substantially improves the results. This is further verified in Sect. 3.1 where BASCOE $\mathrm{NO}_{2}$ stratospheric columns are compared with observations from ground-based UV-visible instruments of the Network for the Detection of Atmospheric Composition Change (NDACC). 


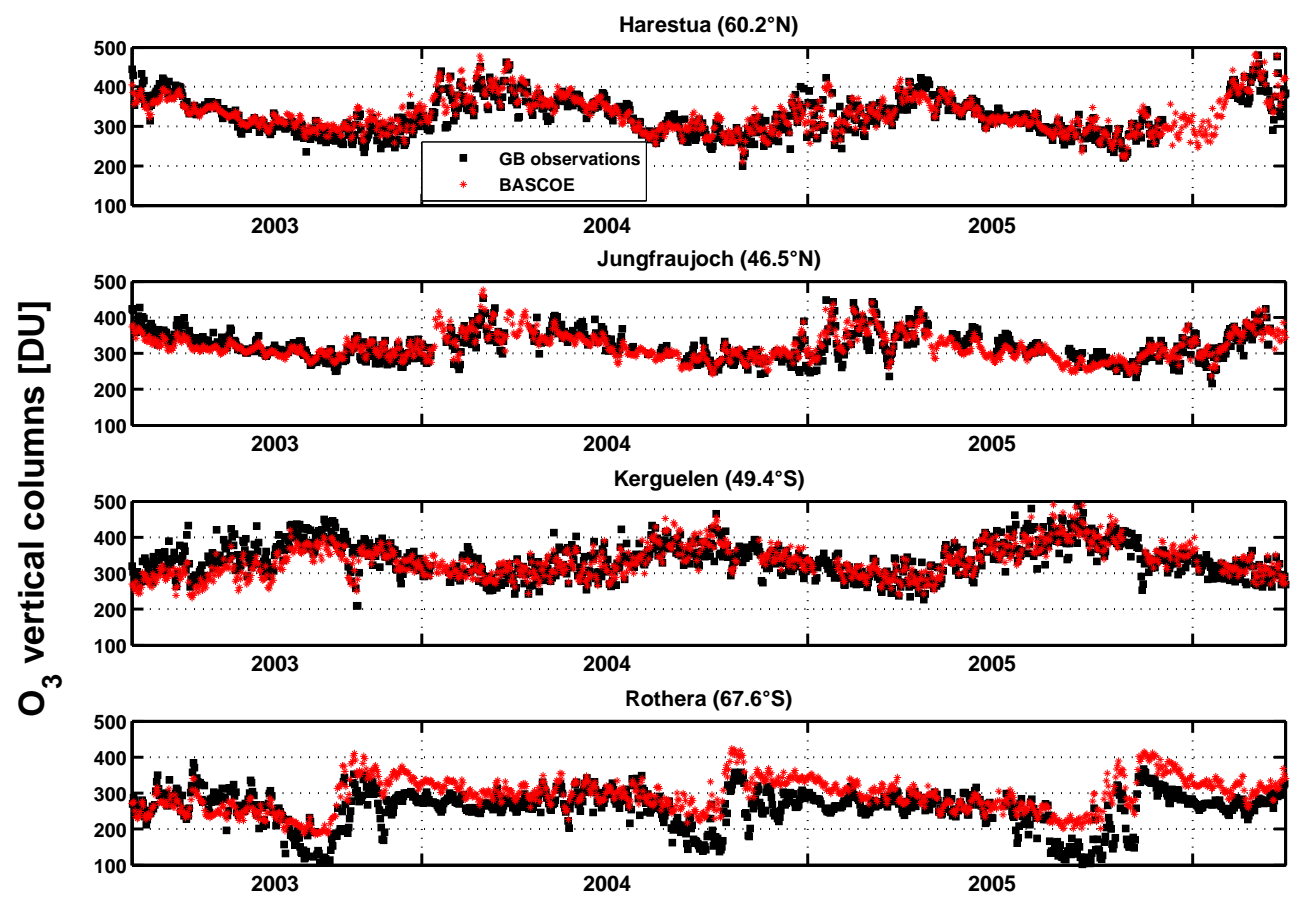

Fig. 1. Time-series of sunset stratospheric $\mathrm{O}_{3}$ vertical columns from BASCOE analysis and ground-based UV-visible observations at 4 NDACC stations (top to bottom): Harestua, Jungfraujoch, Kerguelen and Rothera. Black squares: ground-based observations; red stars: BASCOE analysis.

\section{Verification of model results}

Several studies have been conducted recently (Geer et al., 2006; Vigouroux et al., 2007; Daerden et al., 2007; Errera et al., 2008), where the BASCOE CTM has been extensively evaluated based on $\mathrm{O}_{3}, \mathrm{NO}_{2}, \mathrm{H}_{2} \mathrm{O}, \mathrm{HNO}_{3}, \mathrm{~N}_{2} \mathrm{O}$ and $\mathrm{CH}_{4}$ observations. These results showed that BASCOE is able to reproduce important aspects of the stratospheric composition. Here, the reliability of the BASCOE results is further assessed for ozone, nitrogen dioxide (Sect. 3.1) and bromine monoxide (Sect. 3.2), by means of validation using groundbased, balloon and satellite limb observations.

\subsection{Comparison of modelled and measured stratospheric $\mathrm{O}_{3}$ and $\mathrm{NO}_{2}$ columns}

The measurement data were obtained from zenith sky UVvisible observations, performed at four stations which are part of the NDACC (http://www.ndacc.org). The observations are made during twilight periods for solar zenith angles (SZA) ranging from $86^{\circ}$ to $91^{\circ}$. At all stations, the column densities of $\mathrm{O}_{3}$ and $\mathrm{NO}_{2}$ along the optical path (slant column) have been retrieved using the DOAS (Differential Optical Absorption Spectroscopy) technique (Platt and Stutz, 2006). The analysis is made for $\mathrm{O}_{3}$ in the $435-555 \mathrm{~nm}$ wavelength interval and for $\mathrm{NO}_{2}$ in the $420-470 \mathrm{~nm}$ range. Slant columns are converted into vertical columns using an optical path enhancement factor, or so-called air mass factor (AMF). Since ground-based measurements are made for high SZA, the retrieved $\mathrm{O}_{3}$ and $\mathrm{NO}_{2}$ columns are predominantly of stratospheric origin. For our comparison exercise, simulated ozone and nitrogen dioxide concentration profiles have been interpolated at the location corresponding to each station and for solar zenith angles of $90^{\circ}$ (representative of the ground-based retrieved columns at sunrise and sunset), and then integrated between the tropopause and the highest model level.

Figure 1 presents the modelled and measured stratospheric $\mathrm{O}_{3}$ columns for the period from 04/2003 to 03/2006 for Harestua $\left(60.2^{\circ} \mathrm{N}, 10.7^{\circ} \mathrm{E}\right)$, Jungfraujoch $\left(46.5^{\circ} \mathrm{N}, 7.9^{\circ} \mathrm{E}\right)$, Kerguelen $\left(49.4^{\circ} \mathrm{S}, 70.3^{\circ} \mathrm{E}\right)$ and Rothera $\left(67.6^{\circ} \mathrm{S}, 68.1^{\circ} \mathrm{W}\right)$. A good agreement is found for the entire period for Harestua, Jungfraujoch and Kerguelen with relative differences smaller than $15 \%$. The observed seasonal and short-term dynamical changes are well captured by the simulations. At Rothera, the agreement is reasonable except during ozone-hole and summer conditions, where BASCOE overestimates the stratospheric $\mathrm{O}_{3}$ columns by 50 to $100 \mathrm{DU}$. This confirms the findings of Errera et al. (2008). Note however that the measurements at Rothera have the tendency to underestimate the ozone columns by 10 to $15 \mathrm{DU}$ for ozone hole conditions (Roscoe et al., 2001).

To a large extent, the lower stratospheric $\mathrm{BrO}$ concentration is controlled by $\mathrm{NO}_{2}$ through the termolecular reaction $\mathrm{BrO}+\mathrm{NO}_{2}+\mathrm{M} \rightarrow \mathrm{BrONO}_{2}+\mathrm{M}$. Accurate modelling of nitrogen dioxide is thus a prerequisite to evaluate the stratospheric $\mathrm{BrO}$ amount. 


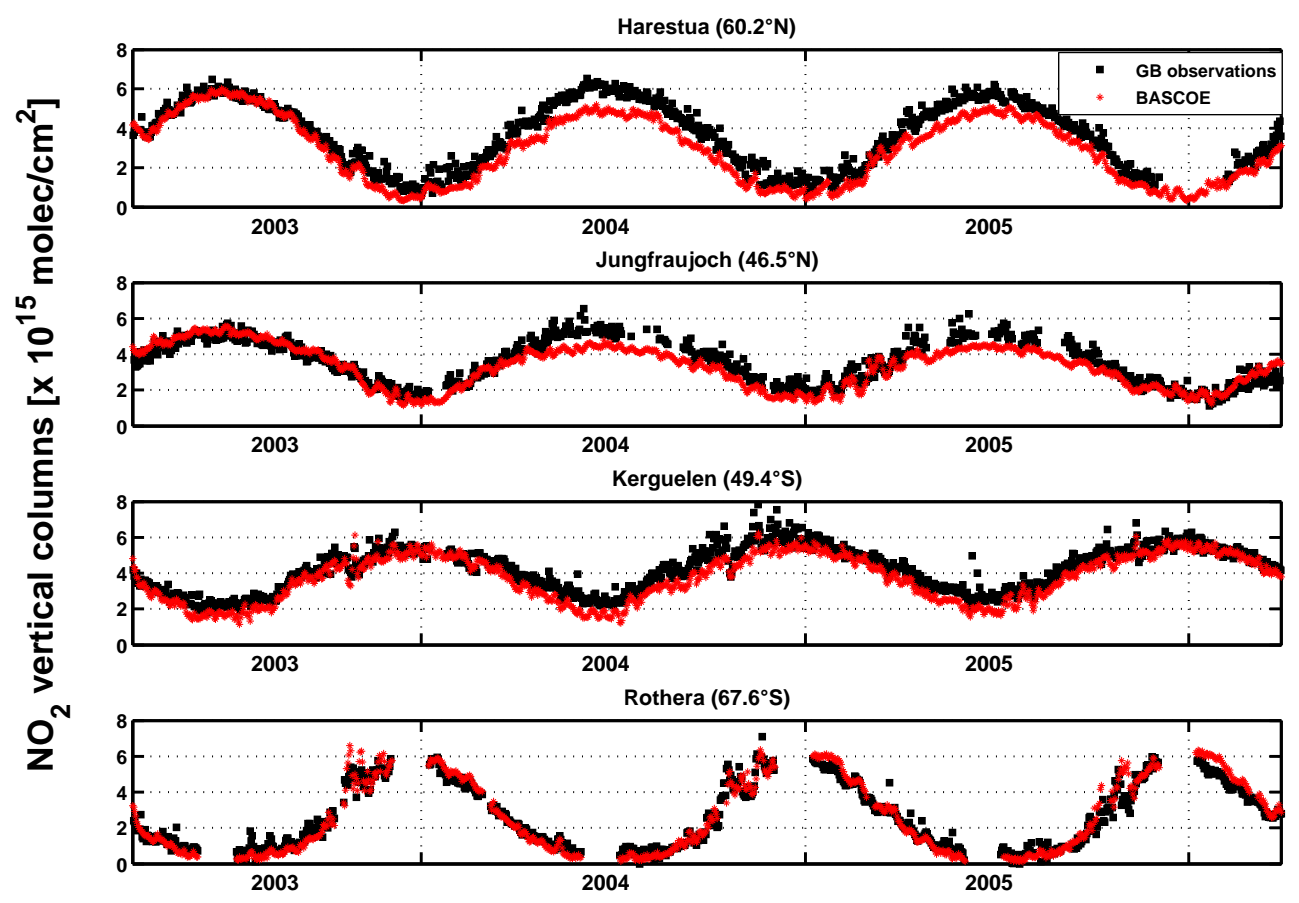

Fig. 2. Time-series of sunset stratospheric $\mathrm{NO}_{2}$ vertical columns from BASCOE analysis and ground-based UV-visible observations at 4 NDACC stations (top to bottom): Harestua, Jungfraujoch, Kerguelen and Rothera. Black squares: ground-based observations; red stars: BASCOE analysis.

Figure 2 shows the simulated and measured stratospheric $\mathrm{NO}_{2}$ columns for Harestua, Jungfraujoch, Kerguelen and Rothera. The results are shown for sunset, but similar agreement is obtained for sunrise conditions. Most significant features of the observed seasonal and short-term $\mathrm{NO}_{2}$ variabilities (related to photochemical and/or dynamical effects) are consistently reproduced by the simulations. However, the model shows a small tendency to underestimate the retrieved $\mathrm{NO}_{2}$ columns. This might be related to the limited time/horizontal resolution and to the fact that the modelled columns are estimated at twilight, conditions where stratospheric $\mathrm{NO}_{2}$ undergoes a rapid variation with time. Sensitivity tests show that the estimation of the modelled stratospheric $\mathrm{NO}_{2}$ columns can be affected by this effect, up to $0.7 \times 10^{15} \mathrm{molec} / \mathrm{cm}^{2}$, with the largest discrepancies in summer. The absolute accuracy of the retrieved stratospheric $\mathrm{NO}_{2}$ columns at NDACC stations can also be limited by (1) uncertainties related to the $\mathrm{NO}_{2}$ absorption crosssections and their temperature dependence (Koike et al., 1997; Roscoe et al., 1999; Vandaele et al., 2005), (2) AMF uncertainties associated with seasonal, meridian and diurnal variations of the $\mathrm{NO}_{2}$ profile shape (Lambert et al., 1999). The overall uncertainty on the retrieved stratospheric $\mathrm{NO}_{2}$ columns is of about $10 \%$. Note that the possibility of a significant contribution to the measured column by tropospheric $\mathrm{NO}_{2}$ from pollution is unlikely since the selected stations are located in clean areas. Nonetheless, the BASCOE model results agree in a satisfactory way with the observations (differences smaller than $1.2 \times 10^{15} \mathrm{molec} / \mathrm{cm}^{2}$ ), knowing the uncertainties on both modelled and measured stratospheric $\mathrm{NO}_{2}$ columns.

\subsection{Comparisons of modelled and measured stratospheric $\mathrm{BrO}$}

The consistency between the stratospheric $\mathrm{BrO}$ profiles, as simulated by the BASCOE model, and correlative data has been verified. For this purpose, the modelled $\mathrm{BrO}$ profiles have been interpolated at the location and at the solar zenith angle of each observation. The measurements reported in this study performed from ground-based, balloon and satellite platforms, are listed in Table 2. These correlative data set sample latitudes extending from polar to tropical regions, with the advantage that the resulting comparisons can be made under a large variety of photochemical regimes.

The stratospheric $\mathrm{BrO}$ vertical profiles obtained by the Microwave Limb Sounder (MLS) on the Aura satellite (Kovalenko et al., 2008) has not been used for our comparisons, since these measurements are sensitive to the $\mathrm{BrO}$ profile over a pressure range from 10 to $3.2 \mathrm{hPa}$, where only a small fraction of the total amount of stratospheric $\mathrm{BrO}$ is present. Furthermore, the estimated precision and accuracy of the data make them unsuitable for our comparison study. 
Table 2. Summary of the BrO observation data sets used for the comparisons with model results.

\begin{tabular}{|c|c|c|c|}
\hline Observation type & Location & Period & Reference \\
\hline \multicolumn{4}{|l|}{ Ground-based DOAS (IASB-BIRA) } \\
\hline Harestua, Norway & $60.22^{\circ} \mathrm{N} 10.75^{\circ} \mathrm{E}$ & 04/2003-03/2006 & Hendrick et al. (2007) \\
\hline Observatoire de Haute-Provence, France & $43.94^{\circ} \mathrm{N} 5.71^{\circ} \mathrm{E}$ & 02/2005-03/2006 & Hendrick et al. (2008b) \\
\hline Reunion Island, France & $21.06^{\circ} \mathrm{S} 55.47^{\circ} \mathrm{E}$ & 07/2004-07/2005 & Theys et al. (2007) \\
\hline \multicolumn{4}{|l|}{ Balloon LPMA/DOAS (U. Heidelberg) } \\
\hline Kiruna, Sweden & $67.84^{\circ} \mathrm{N} 21.06^{\circ} \mathrm{E}$ & 24 March 2004 & Dorf et al. (2006a) \\
\hline Aire sur l'Adour, France & $43.70^{\circ} \mathrm{N} 0.25^{\circ} \mathrm{W}$ & 9 October 2003 & Dorf et al. (2006a) \\
\hline Teresina, Brazil & $5.1^{\circ} \mathrm{S} 42.9^{\circ} \mathrm{W}$ & 17 June 2005 & Dorf et al. (2008) \\
\hline \multicolumn{4}{|l|}{ SCIAMACHY limb (U. Bremen) } \\
\hline & Global & 04/2003-02/2004 & Rozanov et al. (2005) \\
\hline
\end{tabular}

\subsubsection{Comparison to ground-based stratospheric $\mathrm{BrO}$ data}

The ground-based observations have been conducted by IASB-BIRA at three NDACC stations: Harestua, Observatoire de Haute-Provence (OHP) and Reunion Island. The period covered by the simulations and the observations is April 2003-March 2006 at Harestua, February 2005-March 2006 at OHP and July 2004-July 2005 at Reunion Island. The measurements were obtained by zenith-sky UV-visible spectroscopy. The instrumental set-ups are described by Hendrick et al. (2007, 2008b) and Theys et al. (2007). The measured radiances are analysed using the DOAS technique. $\mathrm{BrO}$ differential slant columns densities (DSCDs) are retrieved in the $345-359 \mathrm{~nm}$ wavelength range, taking into account the spectral signature of $\mathrm{BrO}, \mathrm{NO}_{2}, \mathrm{O}_{3}, \mathrm{O}_{4}, \mathrm{HCHO}$, $\mathrm{OClO}$ and the Ring effect. The $\mathrm{BrO}$ cross-sections used are taken from Wilmouth et al. (1999). A detailed description of the BrO DOAS settings can be found in Theys et al. (2007) and Aliwell et al. (2002).

At Harestua and OHP, stratospheric BrO profiles are retrieved by applying a profiling technique to the measured DSCDs. The retrieval algorithm is based on the Optimal Estimation Method (Rodgers, 2000) and has been extensively described in Hendrick et al. (2007). It is based on a forward model that includes a stacked box photochemical model allowing to reproduce the strong diurnal variation of $\mathrm{BrO}$ at twilight. The stratospheric $\mathrm{BrO}$ profiles are retrieved for a solar zenith angle of $80^{\circ}$, separately for sunrise and sunset measurements. The characterization of the information content of the retrieval shows that high sensitivity to the stratospheric $\mathrm{BrO}$ profile is obtained between 12 and $28 \mathrm{~km}$ altitude, with a vertical resolution of approximately $8 \mathrm{~km}$.

Ground-based $\mathrm{BrO}$ partial columns are calculated between $12-20 \mathrm{~km}$ and $20-28 \mathrm{~km}$, in order to take benefit from the vertical resolution offered by the profiling technique, and are compared to BASCOE data. Figures 3 and 4 present the comparisons between modelled and ground-based $\mathrm{BrO}$ partial columns, at Harestua and OHP respectively. The er-

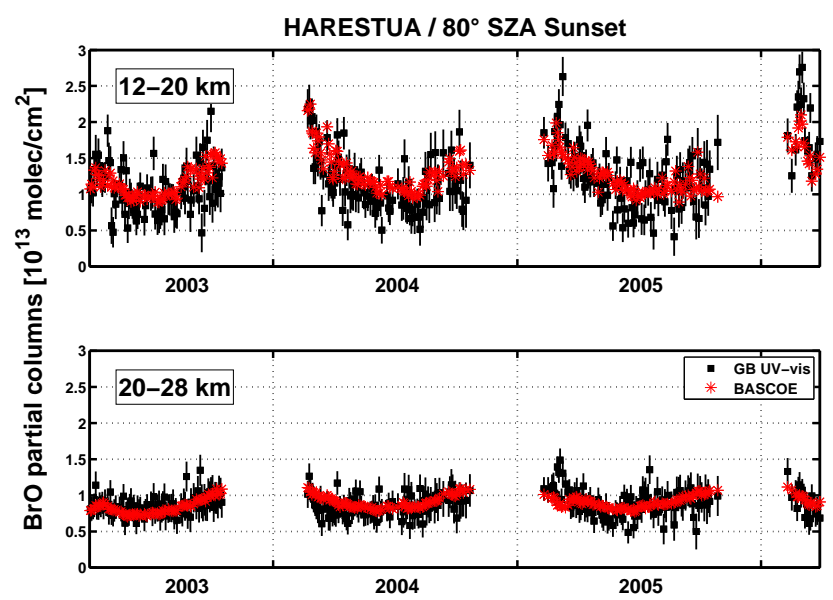

Fig. 3. Comparison between modelled and ground-based stratospheric BrO partial columns, at Harestua for $80^{\circ}$ SZA sunset. The BrO profiles are integrated between $12-20 \mathrm{~km}$ (top) and $20-28 \mathrm{~km}$ (bottom). Black squares: ground-based observations; red stars: BASCOE analysis.

ror bars associated with the ground-based partial columns are estimates of the random and systematic uncertainties of the retrieval. The model and ground-based data are given at $80^{\circ} \mathrm{SZA}$ for sunset. At both stations, the modelled partial columns agree within $20-25 \%$ with the values derived from the ground-based observations. In particular, the seasonality of $\mathrm{BrO}$, directly linked to the $\mathrm{NO}_{2}$ seasonal cycle, is consistently captured by both model and ground-based data. Short-term variations linked to dynamical changes are also shown by both datasets in the lower stratosphere. Although not reproduced here, similar results are found with morning data.

At Reunion Island, the inversion of stratospheric $\mathrm{BrO}$ profiles by applying the profiling technique has been found to be difficult for two reasons: (1) the poorer performance of the instrument in terms of the signal to noise ratio, and (2) the smaller $\mathrm{BrO}$ absorption at tropical latitudes. Consequently, 


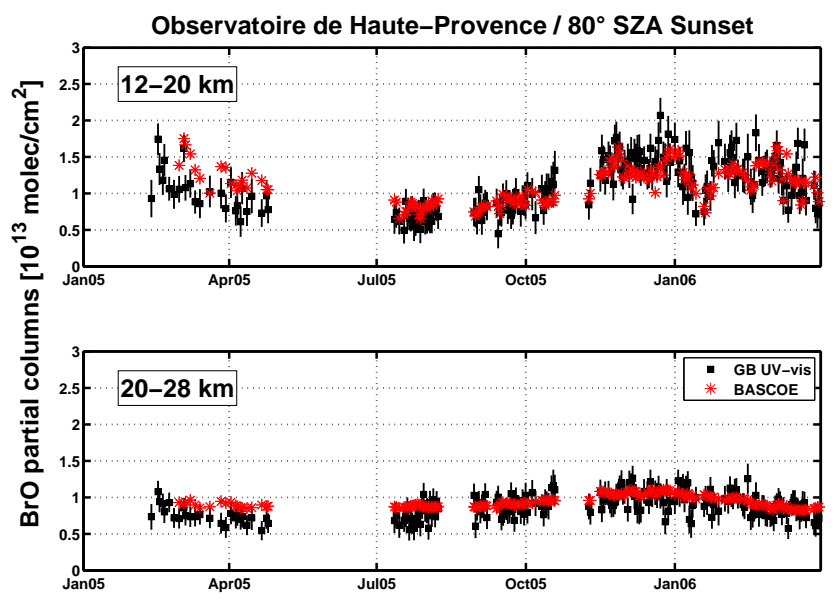

Fig. 4. Same as Fig. 3, at Observatoire de Haute-Provence.

only stratospheric $\mathrm{BrO}$ columns have been retrieved, using an inversion method where the measured slant columns are fitted to radiative transfer simulations of the $\mathrm{BrO}$ slant column (see details in Theys et al., 2007). The error estimate associated to the retrieved stratospheric columns is slightly larger for Reunion-Island than for Harestua and OHP data. For this study, we compare the retrieved and modelled stratospheric $\mathrm{BrO}$ columns only at a single reference SZA (fixed at $80^{\circ}$ for sunset). The comparison between modelled and ground-based stratospheric BrO columns is displayed in Fig. 5. The modelled BrO columns are calculated by integrating the stratospheric $\mathrm{BrO}$ profiles from the tropopause height, based on temperature profiles from ECMWF data, to the upper model level. Figure 5 shows that the modelled $\mathrm{BrO}$ columns are slightly smaller than the columns retrieved from ground-based measurements, but are within the error bars.

\subsubsection{Comparison with LPMA/DOAS balloon profiles}

A detailed description of the LPMA/DOAS (Limb Profile Monitor of the Atmosphere/Differential Optical Absorption Spectroscopy) $\mathrm{BrO}$ measurements used here can be found in Harder et al. (1998, 2000), Pfeilsticker et al. (2000) and Dorf et al. (2006a, b, 2008). The LPMA/DOAS measurements use the solar occultation technique. The $\mathrm{BrO}$ profiles are retrieved using an Optimal Estimation Technique (Rodgers, 2000) applied to the BrO slant column densities measured during the ascent of the balloon. The accuracy of the technique is generally very good (better than $\pm 12 \%$, Harder et al., 1998) and the vertical resolution of the inverted stratospheric $\mathrm{BrO}$ profile is about $2 \mathrm{~km}$. A further independent constraint on $\mathrm{BrO}$, and hence on total stratospheric $\mathrm{Br}_{\mathrm{y}}$, is provided by Langley type observations of $\mathrm{BrO}$ absorption as function of total air mass above float altitude $(>32 \mathrm{~km})$ during each of balloon measurements (e.g., Dorf et al. 2006a).

For the present comparisons, three balloon flights originated from Kiruna, Aire sur l'Adour and Teresina are taken

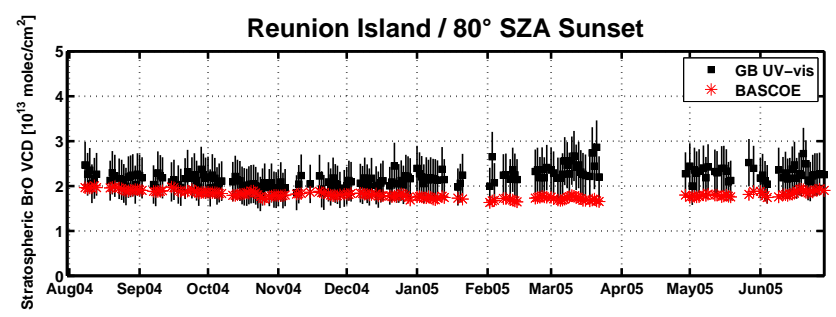

Fig. 5. Comparison between modelled and ground-based stratospheric BrO columns, at Reunion Island for $80^{\circ}$ SZA sunset. Black squares: ground-based observations; red stars: BASCOE analysis.

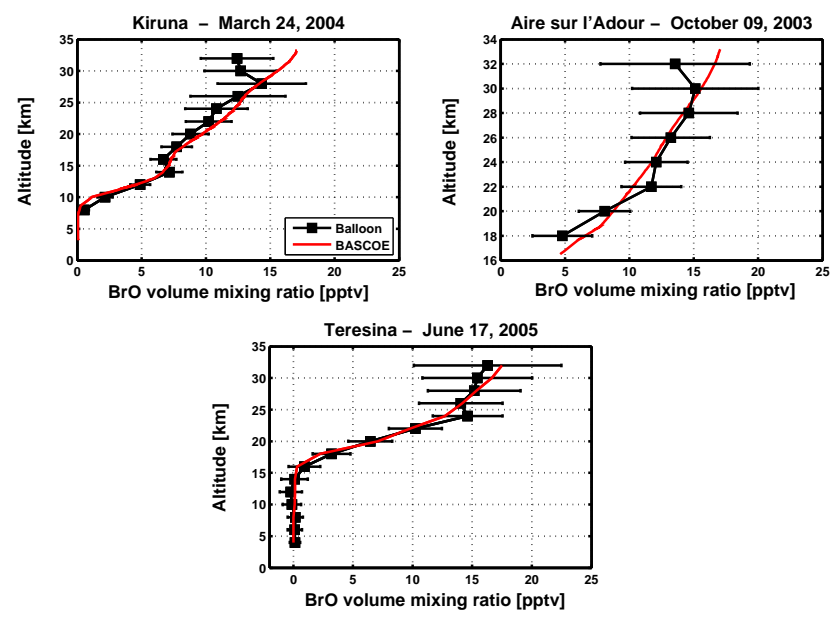

Fig. 6. Comparison between modelled and LPMA/DOAS ascent balloon $\mathrm{BrO}$ profiles at Kiruna, Aire sur l'Adour and Teresina. Black squares: balloon observations; red lines: BASCOE analysis.

into account (see Table 2 for details). The BASCOE BrO profiles have been interpolated to the location of the balloon and at the SZA corresponding to the observation (varying during the ascent of the balloon) in order to have identical photochemical conditions between the balloon and the model profiles. Figure 6 shows the measured BrO balloon profiles together with the model calculation for the three flights. In general, we find a good agreement between the LPMA/DOAS and modelled BrO profiles. The observed differences are within the error bars of the balloon-borne profiles. These comparison results are similar to the ones presented in Feng et al. (2007) and Dorf et al. (2006a, b and 2008).

\subsubsection{Comparison to SCIAMACHY limb profiles}

The SCIAMACHY (Scanning Imaging Absorption Spectrometer for Atmospheric CHartographY) instrument is in operation on the ENVISAT platform since July 2002. In the nadir and limb viewing geometries, the SCIAMACHY instrument measures the sunlight scattered by the Earth's atmosphere or reflected by the surface whereas in the occultation 


\section{BrO partial columns [molec/ $\left./ \mathrm{cm}^{2}\right]$}
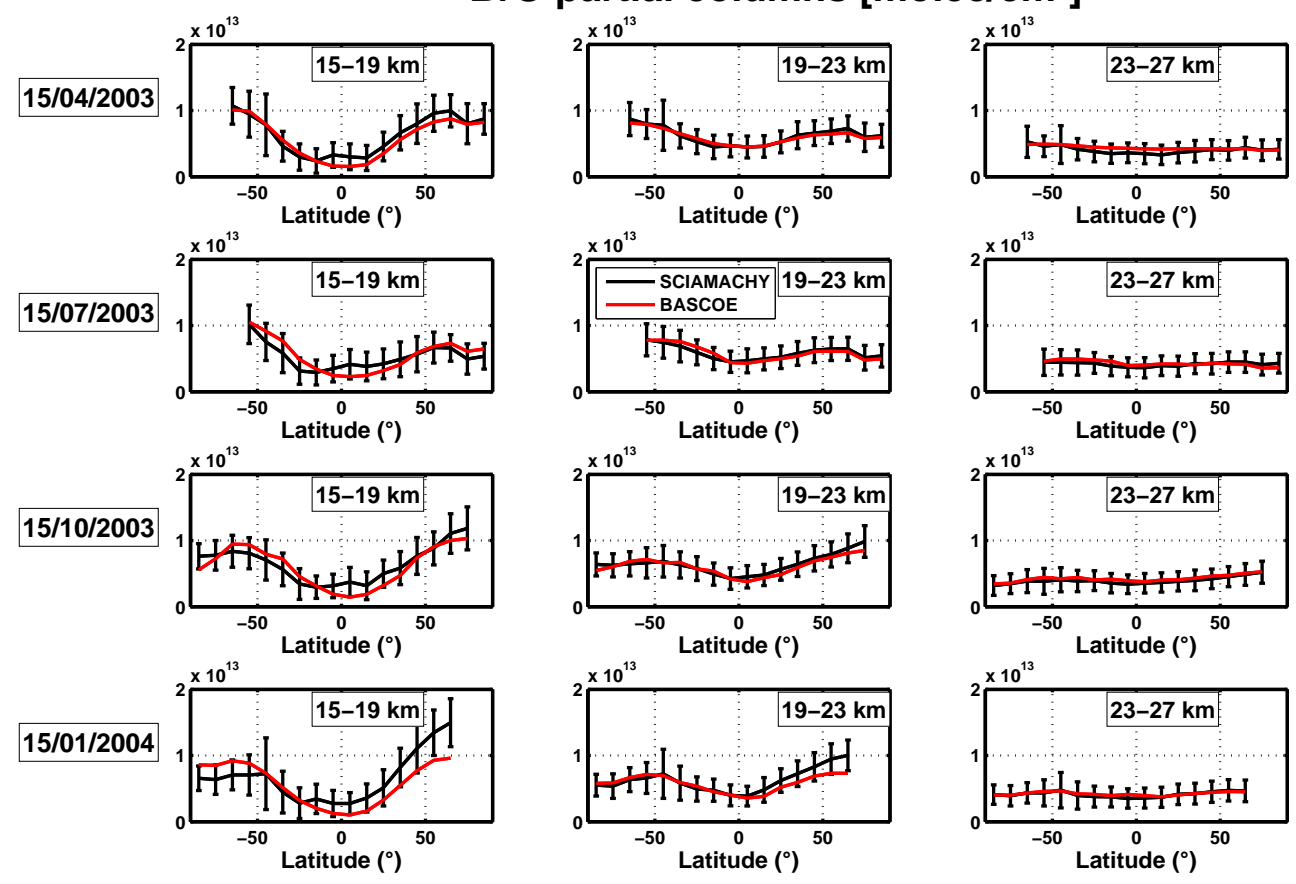

Fig. 7. Zonal means of $\mathrm{BrO}$ partial columns (SZA lower than $85^{\circ}$ ), for three altitude ranges (left plots: 15 to $19 \mathrm{~km}$, centre plots: 19 to $23 \mathrm{~km}$, right plots: 23 to $27 \mathrm{~km}$ ) calculated from SCIAMACHY limb profiles and BASCOE modelled profiles for the 15th of April, July, October (2003) and January (2004). Black lines: SCIAMACHY limb observations; red lines: BASCOE analysis.

mode, the direct solar or lunar light transmitted through the atmosphere is observed. The measurements are performed in eight spectral channels covering the $240-2400 \mathrm{~nm}$ wavelength range with a spectral resolution of 0.2 to $1.5 \mathrm{~nm}$. A detailed description of the instrument and its characteristics can be found in Bovensmann et al. (1999). Among other geophysical data products, stratospheric $\mathrm{BrO}$ profiles can be retrieved from the SCIAMACHY limb spectral measurements (Rozanov et al., 2005; Sinnhuber et al., 2005; Sheode et al., 2006; Sioris et al., 2006) on the global scale (since ENVISAT is in polar sun-synchronous orbit). In this study, we use the $\mathrm{BrO}$ profiles derived at the Institute of Environmental Physics (IUP) at the University of Bremen (scientific product: version 3.2). A detailed description of the retrieval algorithm as well as the results of the error analysis and sensitivity studies can be found in (Rozanov et al., 2005) where, however, a precursor version of the retrieval processor (version 1.x) is discussed. The most recent retrieval version 3.2, used in this study, employs the same inversion algorithm as earlier versions (e.g., version 1.x described in the above cited paper) differing, however, quite strongly in the retrieval parameter settings. For example, a slightly different spectral range (338.0-356.2 $\mathrm{nm}$ ) and a higher reference tangent height (about $35 \mathrm{~km}$ ) were used, Levenberg-Marquardt iterative scheme was replaced by more common Newton-type iterations, and the regularization parameters were optimized. Furthermore, additional information on pressure and tem- perature provided by the ECMWF were used. A more extensive description of the retrieval processor of version 3.2 is presented in (Hendrick et al., 2008b), where also the accuracy of the retrieved $\mathrm{BrO}$ profiles has been assessed. A detailed list of the retrieval parameter settings for the current and previous versions of the retrieval software can be found at the data archive web page of the IUP-Bremen (http: //www.iup.physik.uni-bremen.de/scia-arc). SCIAMACHY limb BrO profiles are retrieved with the highest sensitivity in the $15-27 \mathrm{~km}$ altitude region and the vertical resolution is between 3 and $5 \mathrm{~km}$ (Rozanov et al., 2005; Hendrick et al., 2008b).

For our comparison exercise, we have selected 11 complete days of data (the 15th of each month from April 2003 to February 2004). For each day, modelled and measured BrO partial columns have been calculated and compared for three altitude regions ( 15 to $19 \mathrm{~km}, 19$ to $23 \mathrm{~km}$ and 23 to $27 \mathrm{~km}$ ). Figure 7 shows the comparison results (zonal means, for SZA smaller than $85^{\circ}$ ), for the 15 th of April, July, October of 2003 and January 2004. The error bars represent the standard deviation of the SCIAMACHY partial columns within each latitudinal bin plus an estimated systematic error of $10 \%$ (added in quadrature). The minimum error is determined by the detection limit of the SCIAMACHY limb measurements which is estimated to be about $10^{12} \mathrm{molec} / \mathrm{cm}^{2}$. Considering the uncertainties on satellite measurements, the agreement obtained is satisfying at all latitudes, for all altitude layers. 

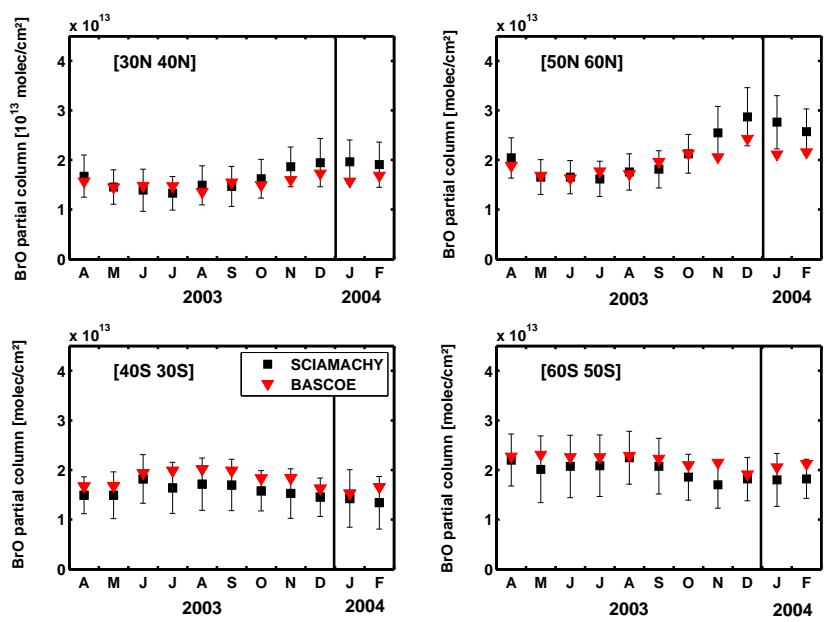

Fig. 8. Comparison of the $15-27 \mathrm{~km} \mathrm{BrO}$ partial columns (zonal means) calculated from the SCIAMACHY limb and BASCOE profiles for 11 days of data sampling the period from April 2003 to February 2004 and for different latitude bands. Black squares: SCIAMACHY limb observations; red triangles: BASCOE analysis.

Comparison results for the $15-27 \mathrm{~km} \mathrm{BrO}$ partial columns for different latitude bands $\left(60^{\circ} \mathrm{S}-50^{\circ} \mathrm{S}, 40^{\circ} \mathrm{S}-30^{\circ} \mathrm{S}\right.$, $30^{\circ} \mathrm{N}-40^{\circ} \mathrm{N}$ and $50^{\circ} \mathrm{N}-60^{\circ} \mathrm{N}$ ) are depicted in Fig. 8, for the 11 days of data (designated by their respective months on the $\mathrm{x}$-axis). It shows that the agreement between BASCOE and SCIAMACHY partial columns is reasonably good; BASCOE data are most of the time within the error bars associated to the SCIAMACHY partial columns. The seasonality of $\mathrm{BrO}$ is also consistently captured at all latitudes by both SCIAMACHY and BASCOE data.

\subsubsection{Discussion}

As shown in previous sections, the model calculation reproduces the observed $\mathrm{BrO}$ generally very well, taking into account the overall errors of the measurements (about 20$25 \%$ ), for the three different types of observations (groundbased, balloon, space-borne limb measurements) used in this study. The seasonal and latitudinal variations are well captured by the model.

Model and measured data agree well assuming a total inorganic bromine loading of 23 pptv. The uncertainty on the contribution of VSLS to stratospheric $\mathrm{Br}_{\mathrm{y}}$ has recently received a lot of attention, and is a topic stressed in the WMO report (2007). Furthermore, the quantification of the inorganic bromine amount at the lower stratospheric entry levels is difficult, because it is controlled by processes with rather large uncertainties (surface emissions, transport and chemical lifetime of brominated short-lived species). A simple way to implement the bromine short-lived species in the model has been considered by assuming that the total $\mathrm{Br}_{\mathrm{y}}$ is coming from a single effective source of $\mathrm{CH}_{3} \mathrm{Br}$ (with a

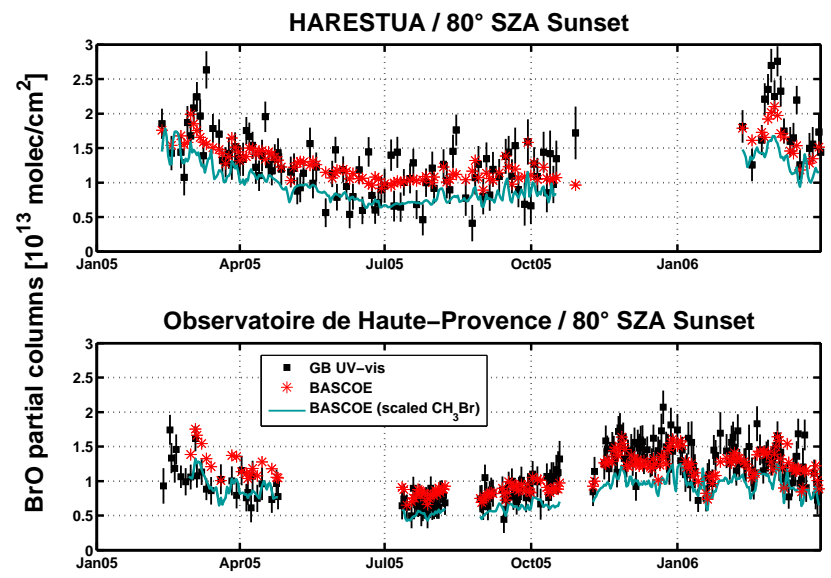

Fig. 9. Comparison between modelled and ground-based stratospheric BrO partial columns (12-20 km altitude range), at Harestua (top) and Observatoire de Haute-Provence (bottom) for the period from January 2005 to March 2006. BASCOE assumes $\left[\mathrm{Br}_{\mathrm{y}}\right]=23 \mathrm{pptv}$ for two different scenarios: (red) stratospheric inorganic bromine has contributions from $\mathrm{CH}_{3} \mathrm{Br}$, halons, VSLS and product gases as described in Sect. 2.1., (green) stratospheric Bry is supplied only by the decomposition of methyl bromide (scaled). Black squares: ground-based observations.

mixing ratio of $23 \mathrm{pptv}$ at the surface). The stratospheric BrO results, from this test scenario, are displayed with green lines in Fig. 9, presenting the lower stratospheric $\mathrm{BrO}$ partial columns (12-20 km altitude range) at Harestua and OHP together with the measured data, for the period from January 2005 to March 2006. It can be seen that, in general, the stratospheric $\mathrm{BrO}$ modelled in this way is substantially smaller than the measured stratospheric BrO. Taking into account that the short-lived source gases are decomposed faster than methyl bromide, the set-up of short-lived species in the model as proposed in Sect. 2.1 leads to a better consistency between simulated and measured stratospheric $\mathrm{BrO}$. This confirms, on a larger dataset, the findings of other studies (Feng et al., 2007; Dorf et al., 2006b, 2008), who found that the agreement between model and balloon data is significantly improved when having explicitly the short-lived source gases.

Sensitivity tests have been carried out in order to estimate the impact on the model results of the uncertainties on the main reaction rate constants (given in the JPL 2006 compilation), following the work presented in Sinnhuber et al. (2002) and Hendrick et al. (2008a). This gives a total error on the daytime $\mathrm{BrO}$ concentration smaller than $15 \%$. Further photochemical uncertainties are kept small by considering in our comparisons, only data for SZA lower than $85^{\circ}$.

Moreover, stratospheric $\mathrm{BrO}$ is strongly dependent on $\mathrm{NO}_{2}$ and the reasonable agreement between modelled and measured $\mathrm{NO}_{2}$ columns at the NDACC stations (see Sect. 3.1), reinforce our confidence in the BrO simulations and in the fact that discrepancies due to non-appropriate 
simulation of $\mathrm{NO}_{2}$ are rather small. Additional comparisons of BASCOE and SCIAMACHY limb profiles were performed for $\mathrm{O}_{3}$ and $\mathrm{NO}_{2}$ (details on SCIAMACHY limb retrieval can be found in Bracher et al., 2007 and Butz et al., 2006). A satisfactory agreement has been found for both species, in accordance with the conclusions of Sect. 3.1. These results further consolidate our modelled $\mathrm{BrO}$ results.

\section{Stratospheric BrO climatology}

\subsection{General approach}

The primary motivation behind the development of a new $\mathrm{BrO}$ climatology, is the retrieval of tropospheric $\mathrm{BrO}$ columns from satellite nadir observations, using a residual approach. To achieve this goal, the stratospheric BrO climatology has to meet specific requirements:

- Global coverage.

- The diurnal variation of $\mathrm{BrO}$ has to be taken into account, since the instruments are sounding the atmosphere under a large range of possible solar zenith angles. However, we restrict ourselves to SZA lower than $80^{\circ}$, because the retrieval of tropospheric $\mathrm{BrO}$ columns from space nadir observations at high solar zenith angles, is largely complicated due to two main reasons: (1) the measured signal is dominated by the absorption in the stratosphere, due to the very large photon paths in the stratosphere and the reduced sensitivity to the troposphere, and (2) stratospheric $\mathrm{BrO}$ has a sharp photochemical variation at twilight, that can lead to photochemical gradients along the slant stratospheric photon path, and even horizontal inhomogeneity of the $\mathrm{BrO}$ field within the measured pixel.

- Stratospheric $\mathrm{BrO}$ is highly variable in time and space, and depends on several parameters and atmospheric conditions. The $\mathrm{BrO}$ climatology must be able to reproduce with enough precision the $\mathrm{BrO}$ profiles for the large variety of possible scenarios. Misrepresentation of important patterns of stratospheric $\mathrm{BrO}$ (e.g. due to the effect of atmospheric dynamics) will lead to artefacts in the retrieved troposheric $\mathrm{BrO}$ columns.

- The stratospheric BrO climatology must provide an effective profile representative of the sounded atmosphere (averaged profile over the measured pixel).

The stratospheric $\mathrm{BrO}$ climatology proposed here is based on a parameterization which reflects the main dynamical and photochemical processes controlling the distribution of $\mathrm{BrO}$ in the stratosphere.

The stratospheric bromine monoxide profile can be written:

$\mathrm{BrO}=\mathrm{Br}_{\mathrm{y}} \times \frac{\mathrm{BrO}}{\mathrm{Br}_{\mathrm{y}}}$
Where $\mathrm{Br}_{\mathrm{y}}$ is the inorganic bromine profile accounting for all inorganic bromine species (active bromine and bromine reservoirs). Since inorganic bromine can be considered as a good chemical tracer due to its long chemical lifetime, Eq. (1) effectively separates the effects on the $\mathrm{BrO}$ vertical distribution due to the dynamics of the atmosphere and the photochemistry. For a given stratospheric air parcel (with a constant $\mathrm{Br}_{\mathrm{y}}$ volume mixing ratio), rapid photochemical reactions between the various inorganic bromine species are taking place and affect the partitioning of $\mathrm{BrO}$ into the inorganic bromine species family $\left(\mathrm{BrO} / \mathrm{Br}_{\mathrm{y}}\right)$. In this study, these two different aspects are treated separately by developing two distinct climatologies. The development of a $\mathrm{Br}_{\mathrm{y}}$ profile climatology is the focus of Sect. 4.2, while a partitioning profile climatology $\left(\mathrm{BrO} / \mathrm{Br}_{\mathrm{y}}\right)$ is presented in Sect. 4.3. The key requirements to derive a suitable stratospheric $\mathrm{BrO}$ profile from Eq. (1) is to obtain sufficient information about the dynamical and photochemical state of the sounded atmosphere.

\subsection{Dynamics of the stratosphere}

Since most of the inorganic bromine molecules are located below $35 \mathrm{~km}$, we mainly focus on the lower and middle stratosphere. Hereafter, we will refer to the lower, middle and upper stratosphere to designate the stratospheric layers from the tropopause to $25 \mathrm{~km}$, from $25 \mathrm{~km}$ to $35 \mathrm{~km}$ and above $35 \mathrm{~km}$, respectively. As already mentioned, the distribution of inorganic bromine in the stratosphere results from the influence of dynamical processes. For typical time scales of the order of months, the transport of air masses in the stratosphere is governed by the mean meridional circulation, which brings inorganic bromine produced in the tropical lower and middle stratosphere to extra-tropical latitudes. In principle, a monthly zonally-averaged $\mathrm{Br}_{\mathrm{y}}$ profile climatology is able to reproduce in a satisfactory way the relevant spatial and temporal variations of stratospheric inorganic bromine due to the meridional circulation (e.g. ascending and descending advection in the tropical and polar regions respectively, Holton 1995). However it fails to represent the $\mathrm{Br}_{\mathrm{y}}$ variability due to shorter dynamical processes. A more sophisticated climatology is thus needed to reproduce the effects on $\mathrm{Br}_{\mathrm{y}}$ due to short-term transport. At the scale of several days, the motion of stratospheric air parcels is driven by zonal winds. As a first approximation, it can be assumed that the air masses are transported adiabatically (motion along quasi-horizontal isentropic surfaces). Zonal winds tend to eliminate the longitudinal gradients of tracers of the stratospheric dynamics $\left(\mathrm{as} \mathrm{Br}_{\mathrm{y}}\right.$ ). The effect on the distribution of $\mathrm{Br}_{\mathrm{y}}$ varies as a function of altitude, latitude and season. Such short-term dynamical effects are well accounted for by the BASCOE 3-D CTM since it uses 6 hourly ECMWF operational analysis of winds and temperatures. This is demonstrated by the fact that short-term changes in measured $\mathrm{O}_{3}$ columns are consistently captured by the model (see Fig. 1 in Sect. 2.1). The important concept introduced in 

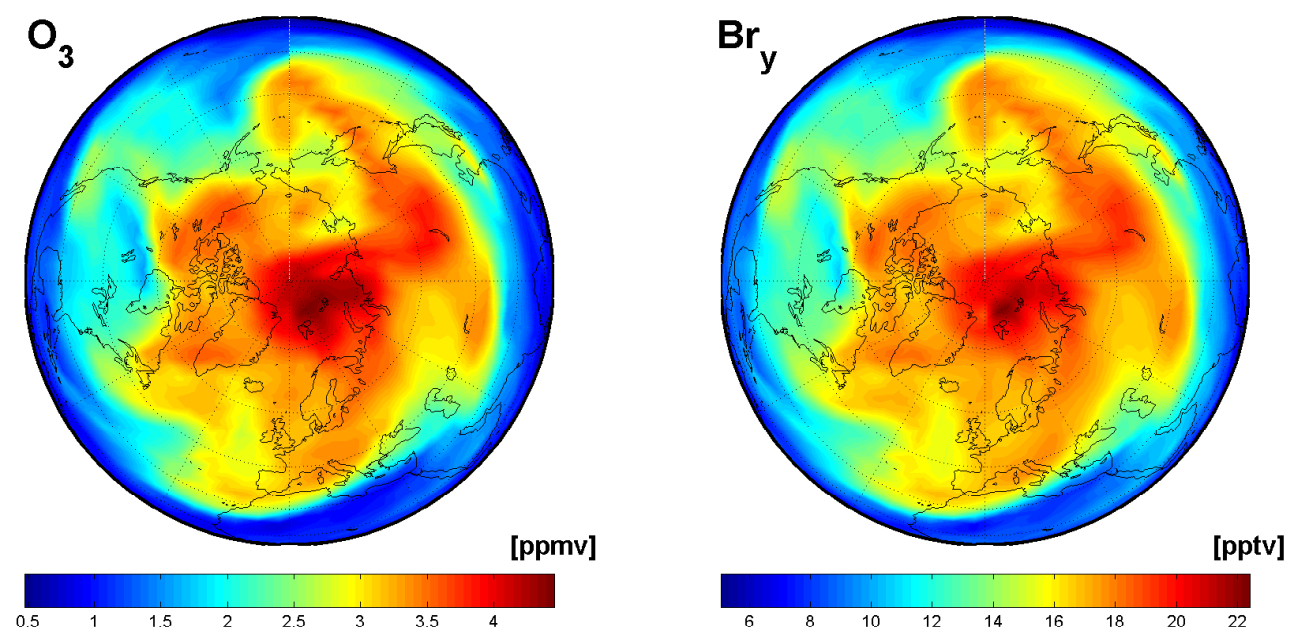

Fig. 10. Example of $\mathrm{BASCOE} \mathrm{O}_{3}$ and $\mathrm{Br}_{\mathrm{y}}$ volume mixing ratios in the northern hemisphere at a potential temperature of $475^{\circ} \mathrm{K}(\sim 60 \mathrm{mb})$, for the 1st March 2004 at 00:00 UT. Blue denotes relatively low volume mixing ratios; red denotes relatively high mixing ratios.

this work to reproduce the effect on stratospheric $\mathrm{Br}_{\mathrm{y}}$ due to short-term transport, is to use stratospheric ozone as a proxy for the dynamical state of the stratosphere. For nonchlorine activated conditions, ozone in the lower and middle stratosphere can be considered as a tracer of the dynamics of the stratosphere (chemical lifetime about one to several months). Since stratospheric inorganic bromine and ozone are both produced mainly in the tropical lower stratosphere and are sensitive to the stratospheric dynamics in a similar way, a correlation between $\mathrm{Br}_{\mathrm{y}}$ and $\mathrm{O}_{3}$ is expected. This is illustrated in Fig. 10, where the $\mathrm{O}_{3}$ and $\mathrm{Br}_{\mathrm{y}}$ volume mixing ratios, as simulated by the BASCOE model, are plotted for a low stratospheric isentropic level for the 1st March 2004 in the northern hemisphere. The large dynamical patterns, characteristic of this season, are obviously reproduced by both ozone and $\mathrm{Br}_{\mathrm{y}}$ VMRs. Based on this noticeable property, we propose a stratospheric $\mathrm{Br}_{\mathrm{y}}$ concentration profile climatology based on a simple parameterization using several inputs: month, latitude and stratospheric ozone column. The dependency of the $\mathrm{Br}_{\mathrm{y}}$ climatology with the month of the year and the latitude allows to reproduce the effect on $\mathrm{Br}_{\mathrm{y}}$ due to the seasonal and latitudinal variations of the meridional circulation, and implicitly for the changes in the zonal winds.

The inorganic bromine profile climatology has been generated by considering the set of $\mathrm{Br}_{\mathrm{y}}$ profiles, simulated by BASCOE for the period from April 2003 to March 2006. $\mathrm{The}_{\mathrm{Br}}$ profiles have been interpolated on a regular altitude grid (step: $1 \mathrm{~km}$ ) covering the stratosphere and classified by month, latitude (18 bands defined by the following boundaries: $\left.-90^{\circ},-80^{\circ}, \ldots, 80^{\circ}, 90^{\circ}\right)$ and $\mathrm{O}_{3}$ column $(19$ blocks of 25 Dobson unit (DU) width centred around $125,150, \ldots$, $550,575 \mathrm{DU})$. The inorganic bromine profile climatology is build by calculating the average of the $\mathrm{Br}_{\mathrm{y}}$ profiles corresponding to each month, latitude band, and $\mathrm{O}_{3}$ column bin. Different weights (proportional to the cell areas) have been assigned to the $\mathrm{Br}_{\mathrm{y}}$ profiles to account for the fact that the model cells vary in size with latitude and thus must have different contributions to the mean (this effect is particularly important close to the poles).

In order to gain better insight into the consistency of the proposed $\mathrm{Br}_{\mathrm{y}}$ parameterization, Figure 11 illustrates the correlation between stratospheric $\mathrm{O}_{3}$ and $\mathrm{Br}_{\mathrm{y}}$ vertical columns, as simulated by BASCOE, for two particular cases: (1) northern mid-latitudes $\left(40^{\circ} \mathrm{N}-50^{\circ} \mathrm{N}\right)$ in March, (2) southern high-latitudes $\left(70^{\circ} \mathrm{S}-60^{\circ} \mathrm{S}\right)$ in September. For northern mid-latitudes, the correlation between $\mathrm{O}_{3}$ and $\mathrm{Br}_{\mathrm{y}}$ vertical columns is excellent. The correlation coefficient is equal to 0.98 . For southern high-latitudes in spring, the correlation deteriorates since stratospheric ozone can no longer be considered as a dynamical tracer (due to its destruction by chlorine species, activated through heterogeneous reactions on the surface of PSCs), and because of the presence of the strong polar dynamical vortex. However, it can be seen that there is only a moderate dispersion of $\mathrm{Br}_{\mathrm{y}}$ columns around the mean, for a given $\mathrm{O}_{3}$ column interval. The relevance of the proposed $\mathrm{Br}_{\mathrm{y}}$ climatology will be assessed and consolidated in Sect. 4.5, through a comprehensive error analysis.

As already mentioned in Sect. 4.1, the bromine monoxide profile climatology is intended to be used for the retrieval of tropospheric $\mathrm{BrO}$ columns from satellite nadir observations. In a first step of the calculation of $\mathrm{BrO}$ profiles (see Eq. 1), stratospheric $\mathrm{Br}_{\mathrm{y}}$ concentration profiles can be derived by using the $\mathrm{Br}_{\mathrm{y}}$ profile parameterization established here, together with the $\mathrm{O}_{3}$ columns retrieved from the observations. This has several advantages (1) it is simple and requires only limited computation resources, (2) the ozone column is a standard product which is retrieved operationally with an excellent accuracy (error lower than 1 or $2 \%$ ), and (3) it guarantees to represent the same air masses and geophysical conditions as the $\mathrm{BrO}$ retrieval. However, the retrieved 

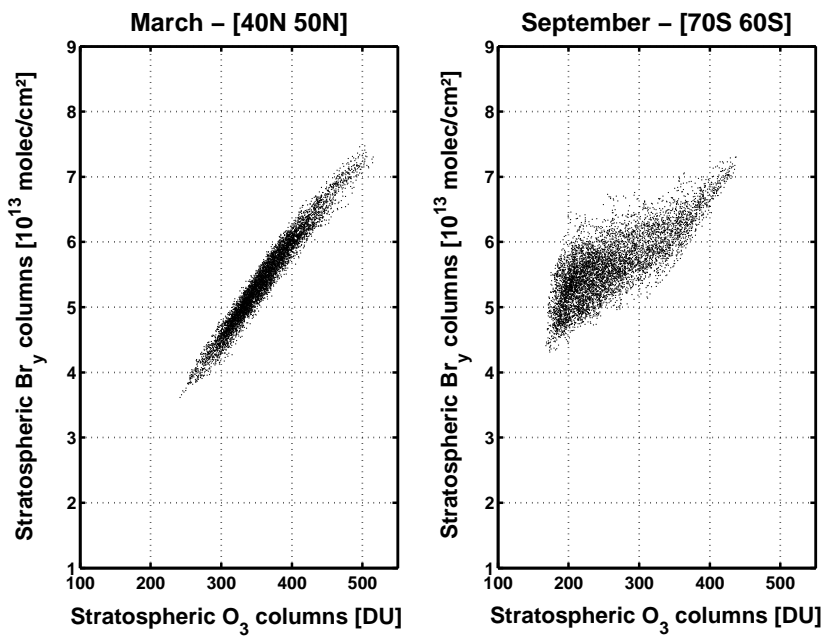

Fig. 11. Correlation between stratospheric $\mathrm{Br}_{\mathrm{y}}$ and $\mathrm{O}_{3}$ vertical columns from BASCOE, for (left) March $\left[40^{\circ} \mathrm{N}-50^{\circ} \mathrm{N}\right]$ and (right) September $\left[70^{\circ} \mathrm{S}-60^{\circ} \mathrm{S}\right]$.

total $\mathrm{O}_{3}$ column contains a small contribution from tropospheric ozone. This can not be accounted for in the $\mathrm{Br}_{\mathrm{y}}$ climatology, since BASCOE does not include any tropospheric processes and is not expected to produce realistic results below the tropopause. In practice, this can be (at least partly) corrected for by subtracting, from the retrieved total $\mathrm{O}_{3}$ column, a tropospheric contribution estimated from a tropospheric ozone climatology (e.g. Logan, 1999).

\subsection{Bromine monoxide photochemistry}

As mentioned earlier, the bromine monoxide profile is obtained by Eq. (1) through a partitioning factor $\left(\mathrm{BrO} / \mathrm{Br}_{y}\right)$ calculated as a function of the altitude, and applied to the inorganic bromine profile. In order to evaluate the ratio $\left(\mathrm{BrO} / \mathrm{Br}_{\mathrm{y}}\right)$, it is necessary to identify the dominant photochemical regimes affecting the bromine partitioning during daytime in the lower and middle stratosphere. A detailed description of the gas-phase and heterogeneous stratospheric bromine chemistry can be found in Lary (1996) and Lary et al. (1996); see also a list of the most relevant reactions in Table 1.

For unperturbed atmospheric conditions, bromine monoxide is in photochemical equilibrium with the bromine reservoirs (mostly $\mathrm{BrONO}_{2}$ and $\mathrm{HOBr}$ ) formed by the reactions:

$\mathrm{BrO}+\mathrm{NO}_{2}+\mathrm{M} \rightarrow \mathrm{BrONO}_{2}+\mathrm{M}$

$\mathrm{BrO}+\mathrm{HO}_{2} \rightarrow \mathrm{HOBr}+\mathrm{O}_{2}$

The loss processes of $\mathrm{BrONO}_{2}$ and $\mathrm{HOBr}$ are dominated by the photolysis and the reaction with $\mathrm{O}$. Note that bromine nitrate can be converted by heterogeneous reactions on sulphate aerosols into $\mathrm{HOBr}$ :

$\mathrm{BrONO}_{2}+\mathrm{H}_{2} \mathrm{O} \stackrel{\text { Het }}{\longrightarrow} \mathrm{HOBr}+\mathrm{HNO}_{3}$

This reaction is expected to play an important role on the partitioning factor before sunrise, but a smaller one on daytime bromine photochemistry (for SZA lower than $80^{\circ}$ ), because of the efficient photolysis of $\mathrm{HOBr}$.

Hence during daytime, bromine nitrate is the major bromine reservoir. As a first approximation, the bromine partitioning factor can be expressed as follows:

$\frac{\mathrm{BrO}}{\mathrm{Br}_{\mathrm{y}}} \approx \frac{\mathrm{BrO}}{\mathrm{BrO}+\mathrm{BrONO}_{2}}=\frac{1}{1+\frac{\mathrm{K}_{\mathrm{BrONO}_{2} \mathrm{NO}_{2}}}{\mathrm{~L}_{\mathrm{BrONO}_{2}}}}$

Where $\mathrm{K}_{\mathrm{BrONO}_{2}}$ and $\mathrm{L}_{\mathrm{BrONO}_{2}}$ are the formation and loss rates of $\mathrm{BrONO}_{2}$, respectively; $\mathrm{NO}_{2}$ is the nitrogen dioxide concentration. This relation expresses the balance between the production and the loss of $\mathrm{BrONO}_{2}$, which affects directly the bromine partitioning factor $\left(\mathrm{BrO} / \mathrm{Br}_{\mathrm{y}}\right)$. It has to be emphasized that (1) the reaction rate of formation of $\mathrm{BrONO}_{2}$ varies with altitude through a temperature dependence, and (2) the loss rate of $\mathrm{BrONO}_{2}$ (mostly photolysis) varies strongly with altitude and solar zenith angle. A sensitivity test shows that it depends only slightly on the $\mathrm{O}_{3}$ column. Consequently, the partitioning ratio $\mathrm{BrO} / \mathrm{Br}_{\mathrm{y}}$ responds very rapidly to any change in $\mathrm{SZA}$ and/or $\mathrm{NO}_{2}$ concentration.

We propose a partitioning factor $\mathrm{BrO} / \mathrm{Br}_{\mathrm{y}}$ profile climatology based on a classification according to: month, latitude, stratospheric $\mathrm{NO}_{2}$ column and solar zenith angle. For this reason, we have calculated the modelled $\mathrm{BrO} / \mathrm{Br}_{\mathrm{y}}$ profiles for the complete period (04/2003 to 03/2006), on the altitude grid already used for the $\mathrm{Br}_{\mathrm{y}}$ climatology. We have selected the BASCOE data corresponding to morning conditions, since the present climatology is designed to be applied for satellite instruments having morning overpasses (GOME, SCIAMACHY, GOME-2). The partitioning factor profile climatology is built by averaging the $\mathrm{BrO} / \mathrm{Br}_{\mathrm{y}}$ profiles on grids of SZA ( $5^{\circ}$ bins, SZA lower than $\left.80^{\circ}\right)$ and stratospheric $\mathrm{NO}_{2}$ columns ( 25 blocks of $0.25 \times 10^{15}$ molec $/ \mathrm{cm}^{2}$ width centred around $0.125,0.375, \ldots, 5.875,6.125 \times 10^{15} \mathrm{molec} / \mathrm{cm}^{2}$ ).

In order to illustrate the concept of the partitioning $\left(\mathrm{BrO} / \mathrm{Br}_{\mathrm{y}}\right)$ climatology, Fig. 12 displays the ratio between the stratospheric $\mathrm{BrO}$ and $\mathrm{Br}_{\mathrm{y}}$ columns as a function of the stratospheric $\mathrm{NO}_{2}$ columns, simulated by BASCOE for August and December and for two solar zenith angles ranges $\left(\mathrm{SZA} \leq 60^{\circ}\right.$ and $\left.60^{\circ}<\mathrm{SZA} \leq 80^{\circ}\right)$.

The inverse dependency of $\mathrm{BrO} / \mathrm{Br}_{\mathrm{y}}$ with $\mathrm{NO}_{2}$ is obvious, as well as the diurnal variation of $\mathrm{BrO}$. However a striking feature can be observed in Fig. 12c, where two photochemical regimes are present in August for low stratospheric $\mathrm{NO}_{2}$ columns. The lower branch of the scatter plot corresponds to perturbed atmospheric conditions in the Antarctic polar 

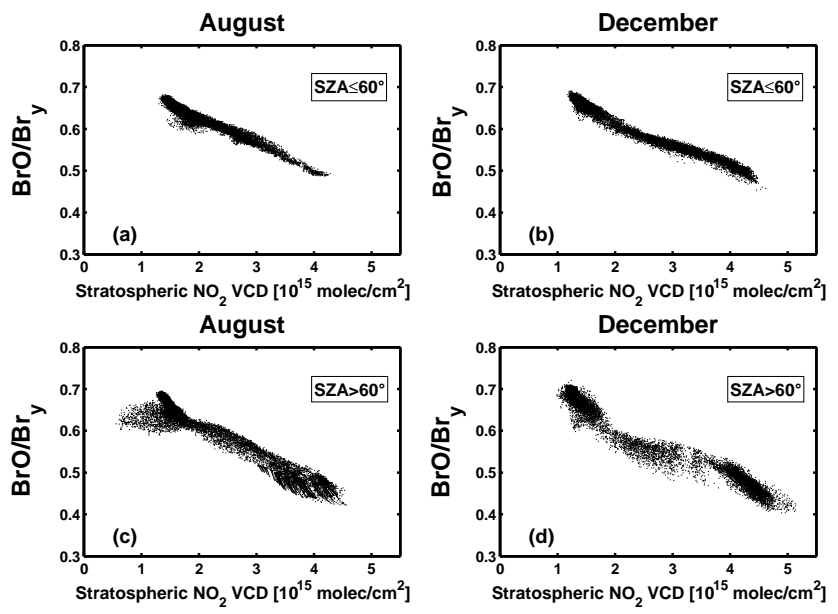

Fig. 12. Ratio between the stratospheric $\mathrm{BrO}$ and $\mathrm{Br}_{\mathrm{y}}$ columns, as a function of the stratospheric $\mathrm{NO}_{2}$ columns (morning conditions; upper plots: $\mathrm{SZA} \leq 60^{\circ}$, lower plots: $60^{\circ}<\mathrm{SZA} \leq 80^{\circ}$ ), estimated from BASCOE data for August (left plots) and December (right plots).

vortex (close to the terminator). Indeed, the polar stratospheric clouds (formed during the winter polar night) provide the surface for a number of heterogeneous reactions leading to the denoxification process and the activation of chlorine species (see e.g. Solomon, 1999). As a consequence, the lower stratospheric inorganic bromine is almost exclusively partitioned between $\mathrm{BrO}$ and $\mathrm{BrCl}$ (formed by the reaction between bromine and chlorine monoxides), and the bromine photochemistry deviates from the standard regime (essentially controlled by stratospheric $\mathrm{NO}_{2}$ ).

It should be noticed that if we restrict ourselves to unperturbed conditions, a parameterization of $\mathrm{BrO} / \mathrm{Br}_{\mathrm{y}}$ with additional entries as the latitude and month is relatively redundant. In first approximation, the stratospheric $\mathrm{NO}_{2}$ column is mainly determined by day length (photolysis of the nitrogen reservoirs) and the solar zenith angle (affecting the diurnal equilibrium $\mathrm{NO}_{2} / \mathrm{NO}$ ). Nevertheless, a general partitioning factor climatology using a classification by latitude and month, is able to reproduce (to some extend) the different photochemical regimes, associated to low $\mathrm{NO}_{2}$ columns, experienced by the stratospheric inorganic bromine species.

From Fig. 12, it can be seen that there is a moderate dispersion of the data around the mean curves. It suggests that the error made by using the adopted parameterization of $\mathrm{BrO} / \mathrm{Br}_{\mathrm{y}}$ is rather small. This will be established in Sect. 4.5 through an error assessment.

The advantage of using the stratospheric $\mathrm{NO}_{2}$ column to parameterize the $\mathrm{BrO} / \mathrm{Br}_{\mathrm{y}}$ ratio is that, besides the simplicity of the method, this information is easily accessible as an intermediate product in the retrieval of total and tropospheric $\mathrm{NO}_{2}$ columns from space nadir measurements (e.g. Boersma et al., 2004).

\subsection{Long-term trend in stratospheric bromine}

Due to the evolution of the organic bromine emissions (Montzka et al., 2003), a positive trend in stratospheric bromine of about $+2.5 \%$ per year has been observed for the 1995-2001 period, while a negative trend of about $-1 \%$ per year has been identified between 2001 and 2005 (Hendrick et al., 2008a). Since model fields used in this study cover three years of data from $04 / 2003$ to $03 / 2006$, the stratospheric $\mathrm{BrO}$ climatology is generalized to account for long-term trend, by adding the year as a new entry of the climatology, in the form of a correction factor.

\subsection{Results and error analysis}

In this section, the stratospheric $\mathrm{BrO}$ vertical columns estimated from the $\mathrm{Br}_{\mathrm{y}}$ and $\mathrm{BrO} / \mathrm{Br}_{\mathrm{y}}$ climatologies are presented. The suitability of the approach described in the previous sections is addressed through an error analysis. To simplify the discussion, we restrict ourselves to the vertical columns at the time of GOME overpass (similar results are obtained for instruments with late morning or early afternoon overpasses, as SCIAMACHY, GOME-2 and OMI). The instrument, aboard the ESA/ERS-2 satellite, flies in a sun-synchronous orbit, implying that fixed latitudes are always sounded at the same local time. For the period from April 2003 to March 2006, the BASCOE model data at GOME overpass has been selected and the stratospheric $\mathrm{BrO}, \mathrm{Br}_{\mathrm{y}}, \mathrm{O}_{3}$ and $\mathrm{NO}_{2}$ vertical columns have been calculated (tropopause heights estimated from ECMWF pressure and temperature profiles, are used). The climatological stratospheric profiles of $\mathrm{Br}_{\mathrm{y}}$ concentration and partitioning ratio $\left(\mathrm{BrO} / \mathrm{Br}_{\mathrm{y}}\right)$ were then evaluated by applying the parameterization, respectively to the calculated $\mathrm{O}_{3}$ and $\mathrm{NO}_{2}$ vertical columns. The climatological stratospheric $\mathrm{BrO}$ profiles and columns are calculated by Eq. (1). For each month and latitude band, the mean of the BrO columns from the climatology is estimated, together with the root mean square of the difference between the parameterized and the BASCOE modelled stratospheric BrO columns. Results are presented in Fig. 13. The same approach has been adopted for the $\mathrm{Br}_{\mathrm{y}}$ columns. In order to assess the importance of the errors originating from the parameterization of $\mathrm{Br}_{\mathrm{y}}$ and $\mathrm{BrO} / \mathrm{Br}_{\mathrm{y}}$, both contributions have been considered separately using the following equation $\left(\mathrm{Br}_{\mathrm{y}}\right.$ and $\mathrm{BrO} / \mathrm{Br}_{\mathrm{y}}$ are independent variables):

$\sigma_{\mathrm{BrO}}^{2}=\left(\mathrm{BrO} / \mathrm{Br}_{\mathrm{y}}\right)^{2} \sigma_{\mathrm{Br}_{\mathrm{y}}}^{2}+\left(\mathrm{Br}_{\mathrm{y}}\right)^{2} \sigma_{\mathrm{BrO} / \mathrm{Br}_{\mathrm{y}}}^{2}$

Figure 13 shows the relative error on the stratospheric $\mathrm{BrO}$ columns due to $\mathrm{Br}_{\mathrm{y}}$ and $\mathrm{BrO} / \mathrm{Br}_{\mathrm{y}}$, respectively. The stratospheric $\mathrm{Br}_{\mathrm{y}}$ vertical columns derived from the climatological profiles and the ratio between the $\mathrm{BrO}$ and $\mathrm{Br}_{\mathrm{y}}$ stratospheric columns, are also presented.

From Fig. 13, it can be stated that the new stratospheric $\mathrm{BrO}$ climatology provides reliable results with a precision better than $14 \%$. It also reveals that: 

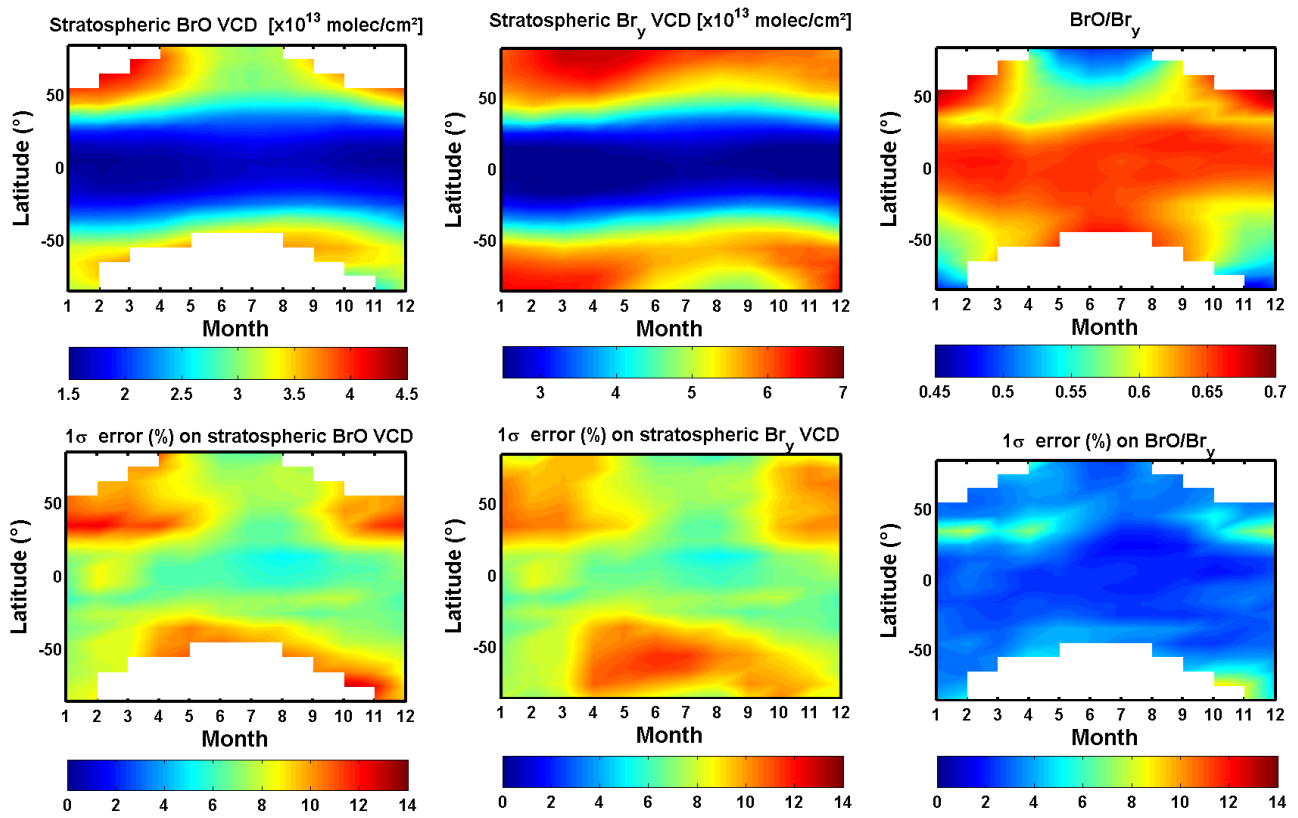

Fig. 13. Results of the BASCOE climatology at GOME overpass. (Upper plots) Monthly zonal averaged of $\mathrm{BrO}$ (left) and $\mathrm{Br}$ (center) stratospheric vertical columns (expressed in $\times 10^{13} \mathrm{molec} / \mathrm{cm}^{2}$ ) and the ratio between $\mathrm{BrO}$ and $\mathrm{Br}$ ycolumns (right). (Lower plots) Standard deviation (expressed in \%) on $\mathrm{BrO}$ columns climatological values and the respective contributions from the $\mathrm{Br}_{\mathrm{y}}$ and $\mathrm{BrO} / \mathrm{Br}_{\mathrm{y}}$ parameterization. The bromine photochemistry for solar zenith angles larger than $80^{\circ}$ is not considered here (white regions).

- the $\mathrm{Br}_{\mathrm{y}}$ climatology produces higher $\mathrm{Br}_{\mathrm{y}}$ columns at mid- and high-latitudes than for tropical regions, as expected from the dependency of the tropopause height with latitude. One can notice smaller values in the Antarctic polar spring, which are mainly related to the air subsidence in the polar vortex.

- except for perturbed chemistry conditions, the errors on the stratospheric BrO columns are dominated by the errors on $\mathrm{Br}_{\mathrm{y}}$. These errors are maximum at mid- and high-latitudes in winter and early spring during major changes in stratospheric dynamics, leading to a larger scatter in the $\mathrm{Br}_{\mathrm{y}} /$ ozone correlations. The moderate errors on $\mathrm{Br}_{\mathrm{y}}$ during Antarctic ozone hole conditions indicate that $\mathrm{Br}_{\mathrm{y}}$ shows small variations within the vortex since the air over the polar region is well isolated. The use of the $\mathrm{O}_{3}$ column helps to identify the vortex and discern air masses with $\mathrm{Br}_{\mathrm{y}}$ amount substantially different.

- the $\mathrm{BrO} / \mathrm{Br}_{\mathrm{y}}$ factor exhibits a strong seasonal variation at mid- and high-latitudes, related to the seasonal cycle of stratospheric $\mathrm{NO}_{2}$.

- the relative error on the stratospheric $\mathrm{BrO}$ columns due to errors on the partitioning factor $\mathrm{BrO} / \mathrm{Br}_{\mathrm{y}}$ is remarkably small for usual photochemical regimes (lower than $8 \%$ ). For perturbed chemistry conditions, the standard deviation can reach $12 \%$ of the $\mathrm{BrO}$ column due to the presence of various photochemical scenarios and dynamical mixing of air with different amount of $\mathrm{NO}_{\mathrm{x}}$.

An important aspect to emphasize is, that the BASCOE stratospheric $\mathrm{O}_{3}$ and $\mathrm{NO}_{2}$ columns used to build the stratospheric $\mathrm{BrO}$ climatology have been validated through comparisons with measured columns obtained from groundbased observations at mid- and high-latitudes in both hemispheres (see Figs. 1 and 2 in Sect. 3.1). The important observed changes in stratospheric $\mathrm{O}_{3}$ and $\mathrm{NO}_{2}$ are consistently reproduced by the model, except for polar ozone in the southern hemisphere in ozone-hole conditions, where BASCOE tends to overestimate the stratospheric $\mathrm{O}_{3}$ columns. In practice, however, this is expected to have a marginal impact on the evaluation of stratospheric $\mathrm{BrO}$ profiles from our climatology since $\mathrm{Br}_{\mathrm{y}}$ show small variations and correlates only slightly with stratospheric ozone for these conditions (see Fig. 11 in Sect. 4.2).

In summary, the error on the stratospheric $\mathrm{BrO}$ column evaluated by the BASCOE climatology, is limited by the accuracy of the modelled BrO. By considering the contribution of the main sources of errors added in quadrature, the overall uncertainty on stratospheric $\mathrm{BrO}$ can be kept below $30 \%$ under most observational conditions. 


\section{Conclusions}

We have presented a new global climatology of stratospheric bromine monoxide, primarily designed for the retrieval of tropospheric $\mathrm{BrO}$ columns from satellite nadir instruments (as GOME, SCIAMACHY and GOME-2), but also of interest for a wider range of applications. The impact of the stratospheric dynamics on the stratospheric $\mathrm{BrO}$ distribution is accounted for by a parameterization based on the ozone column, while the effect of photochemistry on stratospheric $\mathrm{BrO}$ is determined by considering the stratospheric $\mathrm{NO}_{2}$ columns and the solar zenith angle. The adopted parameterization is evaluated based on three years of output data from the BASCOE chemical transport model. Model simulations include full gas phase chemistry and relevant heterogeneous reactions, while dynamics is driven by ECMWF wind fields. Regarding the bromine species, the model calculations use up-to-date photochemistry and a realistic total bromine budget (including a contribution from short-lived bromine source gases).

Although primarily based on model simulations, the climatology is also closely linked to an extensive set of stratospheric $\mathrm{BrO}$ observations from ground-based, balloonborne and satellite (SCIAMACHY) platforms. The excellent overall agreement between the model and the observations demonstrates (1) the level of consistency of the currently available $\mathrm{BrO}$ observational data set, (2) the ability of our model to reproduce the main mechanisms controlling the distribution of stratospheric bromine monoxide. We estimate that the overall uncertainty of the resulting stratospheric $\mathrm{BrO}$ profiles is lower than $30 \%$. However, this error will likely decrease in the future as consolidated kinetic and photochemical data, and improved measurements of inorganic and organic bromine compounds will be available.

The retrieval of tropospheric $\mathrm{BrO}$ from satellite observations and the present climatology requires great care to achieve good accuracy, and the derived tropospheric BrO results will have to be confronted to external measured data in order to test and validate the method. We estimate that an error on the retrieved tropospheric $\mathrm{BrO}$ columns of about $25 \%$ for bromine explosion events and of $50 \%$ for freetropospheric $\mathrm{BrO}$ background conditions may be attributed to the stratospheric $\mathrm{BrO}$ correction. The precise value mainly depends on the observation geometry, surface reflectivity and the $\mathrm{BrO}$ partitioning in both stratosphere and troposphere.

The consequences to infer tropospheric $\mathrm{BrO}$ columns from satellite nadir measured total $\mathrm{BrO}$ columns and the present BASCOE stratospheric $\mathrm{BrO}$ climatology will be further investigated in a future paper.

Acknowledgements. This research has been financially supported by the Belgium Prodex 8 contract NOy-Bry and the Ozone SAF (BrO visiting scientist) project. Q. Errera and S. Chabrillat are supported by the Belgian Federal Science Policy in the framework of the BASCOE Prodex project (PEA 90125). The authors wish to thank M.P. Chipperfield for providing us with SLIMCAT data, and ECMWF for providing us with meteorological analysis.

The ozone and nitrogen dioxide ground-based data used in this publication was obtained as part of the Network for the Detection of Atmospheric Composition Change (NDACC) and is publicly available (see http://www.ndacc.org).

The SCIAMACHY limb BrO retrieval activity was partially funded by the German Ministry of Education and Research (BMF) through the German Aerospace Center (DLR) within the SADOS project (50EE0727). The IUP Bremen group thanks the European Centre for Medium-Range Weather Forecasts (ECMWF) for providing the pressure and temperature information (ECMWF Special Project SPDECDIO). Some data shown here were calculated on German HLRN (High-Performance Computer Center North) and NIC/JUMP (Jülich Multiprocessor System). Services and support are gratefully acknowledged.

Edited by: W. Lahoz

\section{References}

Aliwell, S. R., Van Roozendael, M., Johnston, P. V., Richter, A., Wagner, T., et al.: Analysis for $\mathrm{BrO}$ in zenith-sky spectra: An intercomparison exercise for analysis improvement, J. Geophys. Res., 107, D140, doi:10.1029/2001JD000329, 2002.

Bingen, C., Fussen, D., and Vanhellemont, F.: A global climatology of stratospheric aerosol size distribution parameters derived from SAGE II data over the period 1984-2000: 1. Methodology and climatological observations, J. Geophys. Res., 109, D06201, doi:10.1029/2003JD003518, 2004.

Bobrowski, N., Höninger, G., Galle, B., and Platt, U.: Detection of bromine monoxide in a volcanic plume, Nature, 423, 273-276, 2003.

Boersma, K. F., Eskes, H. J., and Brinksma, E. J.: Error analysis for tropospheric $\mathrm{NO}_{2}$ retrieval from space, J. Geophys. Res., 109, D04311, doi:10.1029/2003JD003962, 2004.

Bovensmann, H., Burrows, J. P., Buchwitz, M., Frerick, J., Noël, S., Rozanov, V. V., Chance, K.V., Goede, A. P. H., SCIAMACHY: Mission objectives and Measurement Modes, J. Atm. Sci., 56, 127-150, 1999.

Bracher, A., Amekudzi, L., Bramstedt, K., Eichmann, K.-U., Rozanov, A., von Savigny, C., and Burrows, J. P.: Global and Validation of SCIAMACHY O3 and $\mathrm{NO}_{2}$ profiles from OL3.0 and IUP/IFE retrieval with collocated measurements from ACEFTS, GOMOS, HALOE, MIPAS, POAM III and SAGE II, in: Proceedings of the ENVISAT Symposium 2007, 23-27 April 2007, Montreux, Switzerland, ESA Publications Division, Nordwijk, The Netherlands, SP-636, 463472br.pdf, 2007.

Butler, J. H., King, D. B., Lobert, J. M., Montzka, S. A., YvonLewis, S. A., Hall, B. D., Warwick, N. J., Mondeel, D. J., Aydin, M., and Elkins, J. W.: Oceanic distributions and emissions of short-lived halocarbons, Global Biogeochem. Cy., 21, GB1023, doi:10.1029/2006GB002732, 2007.

Butz, A, Bösch, H., Camy-Peyret, C., Chipperfield, M., Dorf, M., Dufour, G., Grunow, K., Jeseck, P., Kühl, S., Payan, S., Pepin, I., Pukite, J., Rozanov, A., von Savigny, C., Sioris, C., Wagner, T., Weidner, F., and Pfeilsticker, K.: Inter-comparison of stratospheric $\mathrm{O}_{3}$ and $\mathrm{NO}_{2}$ abundances retrieved from balloon borne di- 
rect sun observations and Envisat/SCIAMACHY limb measurements, Atmos. Chem. Phys., 6, 1293-1314, 2006,

http://www.atmos-chem-phys.net/6/1293/2006/.

Carpenter, L. J. and Liss, P. S.: On temperature sources of bromoform and other reactive organic bromine gases, J. Geophys. Res. D., 105(D16), 20539-20547, 2000.

Chance, K.: Analysis of BrO measurements from the Global Ozone Monitoring Experiment, Geophys. Res. Lett., 25, 3335-3338, 1998.

Daerden, F., Larsen, N., Chabrillat, S., Errera, Q., Bonjean, S., Fonteyn, D., Hoppel, K., and Fromm, M.: A 3-D-CTM with detailed online PSC-microphysics : analysis of the Antarctic winter 2003 by comparison with satellite observations, Atmos. Chem. Phys., 7, 1755-1772, 2007,

http://www.atmos-chem-phys.net/7/1755/2007/.

Dorf, M., Bösch, H., Butz, A., Camy-Peyret, C., Chipperfield, M., Engel, A., Goutail, F., Grunow, K., Hendrick, F., Hrechanyy, S., Naujokat, B., Pommereau, J.-P., Van Roozendael, M., Sioris, C., Stroh, F., Weidner, F., and Pfeilsticker, K.: Balloon-borne stratospheric $\mathrm{BrO}$ measurements: Intercomparisons with ENVISAT/SCIAMACHY BrO limb profiles, Atmos. Chem. Phys., 6, 2483-2501, 2006a, http://www.atmos-chem-phys.net/6/2483/2006/.

Dorf, M., Butler, J. H., Butz, A. , Camy-Peyret, C., Chipperfield, M. P., Kritten, L., Montzka, S. A., Simmes, B., Weidner, F., and Pfeilsticker,K.: Long-term observations of stratospheric bromine reveal slow down in growth, Geophys. Res, Lett., 33, L24803, doi:10.1029/2006GL027714 2006b.

Dorf, M., Butz, A., Camy-Peyret, C., Chipperfield, M. P., Kritten, L., and Pfeilsticker, K.: Bromine in the tropical troposphere and stratosphere as derived from balloon-borne $\mathrm{BrO}$ observations, Atmos. Chem. Phys., 8, 7265-7271, 2008, http://www.atmoschem-phys.net/8/7265/2008/.

Errera, Q. and Fonteyn, D.: Four-dimensional variational chemical assimilation of CRISTA stratospheric measurements, J. Geophys. Res., 106, 12253-12265, 2001.

Errera, Q., Daerden, F., Chabrillat, S., Lambert, J.C., Lahoz, W.A., Viscardy, S., Bonjean, S., and Fonteyn, D.: 4D-Var Assimilation of MIPAS Chemical Observations: Ozone and Nitrogen Dioxide Analysis, Atmos. Chem. Phys., 8, 6169-6187, 2008, http://www.atmos-chem-phys.net/8/6169/2008/.

Feng, W., Chipperfield, M. P., Dorf, M., Pfeilsticker, K., and Ricaud, P.: Mid-latitude ozone changes: studies with a 3-D CTM forced by ERA-40 analyses, Atmos. Chem. Phys., 7, 2357-2369, 2007, http://www.atmos-chem-phys.net/7/2357/2007/.

Fitzenberger, R., Bösch, R., Camy-Peyret, C., Chipperfiel, M. P.,Harder, H., Platt, U., Sinnhuber, B.-M., Wagner, T., and Pfeilsticker, K.: First profile measurements of tropospheric BrO, Geophys. Res. Lett., 27, 2921-2924, 2000.

Frieß, U., Hollwedel, J., König-Langlo, G., Wagner, T., and Platt, U.: Dynamics and chemistry of tropospheric bromine explosion events in the Antarctic coastal region, J. Geophys. Res., 109, D06305, doi:10.1029/2003JD004133, 2004.

Fromm, M., Alfred, J., and Pitts, M.: A unified, long-term, highlatitude stratospheric aerosol and cloud database using SAM II, SAGE II, and POAM II/III data: Algorithm description, database definition, and climatology, J. Geophys. Res., 108(D12), 4366, doi:10.1029/2002JD002772, 2003.

Geer, A. J., Lahoz, W. A., Bekki, S., Bormann, N., Errera, Q., Es- kes, H. J., Fonteyn, D., Jackson, D. R., Juckes, M. N., Massart, S., Peuch, V.-H., Rharmili, S., and Segers, A.: The ASSET intercomparison of ozone analysis: method and first results, Atmos. Chem. Phys., 6, 5445-5474, 2006,

http://www.atmos-chem-phys.net/6/5445/2006/.

Harder, H., Camy-Peyret, C., Ferlemann, F., Fitzenberger, R., Hawat, T., Osterkamp, H., Perner, D., Platt, U., Schneider, M., Vradelis, P., and Pfeilsticker, K.: Stratospheric BrO Profiles Measured at Different Latitudes and Seasons: Atmospheric Observations, Geophys. Res. Lett., 25, 3843-3846, 1998.

Harder, H., Bösch, H., Camy-Peyret, C., Chipperfield, M., Fitzenberger, R., Payan, S., Perner, D., Platt, U., Sinnhuber,B., and Pfeilsticker, K.: Comparison of measured and modeled stratospheric BrO: Implications for the total amount of stratospheric bromine, Geophys. Res. Lett., 27, 3695-3698, 2000.

Hausmann, M. and Platt, U.: Spectroscopic measurement of bromine oxide and ozone in the high Arctic during Polar Sunrise Experiment 1992, J. Geophys. Res., 99, 25399-25414, 1994.

Hebestreit, K., Stutz, J., Rosen, D., Matveiv, V., Peleg, M., Luria, M., and Platt, U.: DOAS measurements of tropospheric bromine oxide in mid-latitudes, Science, 283, 55-57, 1999.

Hendrick, F., Van Roozendael, M., Chipperfield, M. P., Dorf, M., Goutail, F., Yang, X., Fayt, C., Hermans, C., Pfeilsticker, K., Pommereau, J.-P., Pyle, J. A., Theys, N., and De Mazière, M.: Retrieval of stratospheric and tropospheric BrO profiles and columns using ground-based zenith-sky DOAS observations at Harestua, $60^{\circ} \mathrm{N}$, Atmos. Chem. Phys., 7, 4869-4885, 2007, http://www.atmos-chem-phys.net/7/4869/2007/.

Hendrick, F., Johnston, P. V., De Mazière, M., Fayt, C., Hermans, C., Kreher, K., Theys, N., and Van Roozendael, M.: Onedecade trend analysis of stratospheric $\mathrm{BrO}$ over Harestua $\left(60^{\circ} \mathrm{N}\right)$ and Lauder $\left(45^{\circ} \mathrm{S}\right)$ reveals a decline, Geophys. Res. Lett., 35, L14801, doi:10.1029/2008GL034154, 2008a.

Hendrick, F., Rozanov, A., Johnston, P. V., Bovensmann, H., De Mazière, M., Fayt, C., Hermans, C., Kreher, K., Lotz, W., Theys, N., Burrows, J. P., and Van Roozendael, M.: Multi-year comparison of stratospheric $\mathrm{BrO}$ vertical profiles retrieved from SCIAMACHY limb and ground-based UV-visible measurements, accepted for publication in Atmos. Meas. Tech. Discuss., 2008b.

Holton, J. R., Haynes, P. H., McIntyre, M. E., Douglass, A. R., Rood, R. B., and Pfister, L.: Stratosphere-Troposphere Exchange, Rev. Geophys., 33(4), 403-439, 1995.

Hönninger, G. and Platt, U.: Observations of $\mathrm{BrO}$ and its vertical distribution during surface ozone depletion at Alert, Atmos. Environ., 36, 2481-2489, 2002.

Koike, M., Kondo, Y., Matthews, W. A., Johnston, P. V., et al.: Assessment of the uncertainties in the $\mathrm{NO}_{2}$ and $\mathrm{O}_{3}$ measurements by visible spectrometers, J. Atm. Chem., 32, 121-145, 1999.

Kovalenko, L. J., Livesey, N. L., Salawitch, R. J., Camy-Peyret, C., Chipperlfield, M. P., Cofield, R. E., Dorf, M., Drouin, B. J., Froidevaux, L., Fuller, R. A., Goutail, F., Jarnot, R. F., Jucks, K., Knosp, B. W., Lambert, A., MacKenzie, I. A., Pfeilsticker, K., Pommereau, J.-P., Read, W. G., Santee, M. L., Schwartz, M. J., Snyder, W. V., Stachnik, R., Stek, P. C., Wagner, P. A., and Waters, J. W.: Validation of Aura Microwave Limb Sounder BrO observations in the stratosphere, J. Geophys. Res., 112, D24S41, doi:10.1029/2007JD008817, 2007.

Kreher, K., Johnston, P. V., Wood, S. W., Nardi, B., and Platt, U.: Ground-based measurements of tropospheric and strato- 
spheric $\mathrm{BrO}$ at Arrival Heights, Antartica, Geophys. Res. Lett., 24, 3021-3024, 1997.

Lambert, J.-C., Van Roozendael, M., De Mazière, M., Simon, P. C., Pommereau, J.-P., Goutail, F., Sarkissian, A., and Gleason , J. F. : Investigation of pole-to-pole performances of spaceborne atmospheric chemistry sensors with the NDSC, J. Atmos. Sci., 56, 176-193, 1999.

Lary, D. J.: Gas phase atmospheric bromine photochemistry, J. Geophys. Res., 101, 1505-1516, 1996.

Lary, D. J., Chipperfield, M. P., Toumi, R., and Lenton, T.: Heterogeneous atmospheric bromine photochemistry, J. Geophys. Res., 101, 1489-1504, 1996.

Lary, D. J.: Halogens and the chemistry of the free troposphere, Atmos. Chem. Phys., 5, 227-237, 2005, http://www.atmos-chem-phys.net/5/227/2005/.

Leser, H., Höninger, G., and Platt, U.: Max-DOAS measurements of $\mathrm{BrO}$ and $\mathrm{NO}_{2}$ in the marine boundary layer, Geophys. Res. Lett., 30, 1537, doi:10.1029/2002GL015811, 2003.

Logan, J. A.: An analysis of ozonesonde data for the troposphere: Recommendation for testing 3-D models and development of a gridded climatology for tropospheric ozone, J. Geophys. Res., 104, 16115-16149, 1999.

McElroy, M. B., Salawitch, R. J., Wofsy, S. C., and Logan, J. A.: Reductions of Antarctic ozone due to synergistic interactions of chlorine and bromine, Nature, 321, 759-762, 1986.

Montzka, S. A., Butler, J. H., Hall, B. D., Mondeel, D. J., and Elkins, J. W.: A decline in tropospheric organic bromine, Geophys. Res. Lett., 30(15), 1826, doi:10.1029/2003GL017745, 2003.

Pfeilsticker, K., Sturges, W.T., Bösch, H., Camy-Peyret, C., Chipperfield, M. P., Engel, A., Fitzenberger, R., Müller, M., Payan, S., and Sinnhuber, B.-M.: Lower stratospheric organic and inorganic bromine budget for the arctic winter 1998/99, Geophys. Res. Lett., 27, 3305-3308, 2000.

Platt, U. and Stutz, J.: Differential Optical Absorption Spectroscopy (DOAS), Principle and Applications, ISBN-3-34021193-4, Springer Verlag, Heidelberg, 2006.

Pundt, I., Pommereau, J.-P., Chipperfield, M. P., Van Roozendael, M., and Goutail, F.: Climatology of the stratospheric $\mathrm{BrO}$ vertical distribution by balloon-borne UV-visible spectrometry, J. Geophys. Res., 107(D24), 4806, doi:10.1029/2002JD002230, 2002.

Quack, B., Atlas, E., Petrick, G., Stroud, V., Schauffler, S., and Wallace, D. W. R.: Oceanic bromoform sources for the tropical atmosphere, Geophys. Res. Lett., 31, L23S05, doi:10.1029/2004GL020597, 2004.

Richter, A., Wittrock, F., Ladstätter-Weissenmayer, A., and Burrows, J. P.: GOME measurements of stratospheric and tropospheric BrO, Adv. Space Res., 29, 1667-1672, 2002.

Rodgers, C. D.: Inverse Methods for Atmospheric Sounding, Theory and Practice, World Scientific Publishing, Singapore-NewJersey-London-Hong Kong, 2000.

Roscoe, H. K., Johnston, P. V., Van Roozendael, M., Richter, A., et al.: Slant column measurements of $\mathrm{O}_{3}$ and $\mathrm{NO}_{2}$ during the NDSC intercomparison of zenith-sky UV-visible spectrometers in June 1996, J. Atmos. Chem., 32, 281-314, 1999.

Roscoe, H. K., Hill, J. G. T., Jones, A. E., and Sarkissian, A.: Improvements of the accuracy of zenith-sky measurements of total ozone by visible spectrometers II: use of daily air-mass factors,
J. Quant. Spectrosc. Radiat. Trans. 68, 327-336, 2001.

Rozanov, A., Bovensmann, H., Bracher, A., Hrechanyy, S., Rozanov, V., Sinnhuber, M., Stroh, F., and Burrows, J. P.: $\mathrm{NO}_{2}$ and $\mathrm{BrO}$ vertical profile retrieval from SCIAMACHY limb measurements: Sensitivity studies, Adv. Space Res., 36(5), 846-854, doi:10.1016/j.asr.2005.03.013, 2005.

Salawitch, R. J., Weisenstein, D. K., Kovalenko, L. J., Sioris, C. E., Wennberg, P. O., Chance, K., Ko, M. K. W., and McLinden, C. A.: Sensitivity of ozone to bromine in the lower stratosphere, Geophys. Res. Lett., 32, L05811, doi:10.1029/2004GL021504, 2005.

Salawitch R. J.: Atmospheric chemistry: biogenic bromine, Nature, 439, 275-277, 2006.

Sander, S. P., Friedl, R. R., Golden, D. M., Kurylo, M. J., Huie, R. E., Orkin, V. L., Moortgaat, G. K., Ravishankara, A. R., Kolb, C. E., and Molina, M. J.: Chemical Kinetics and Photochemical Data for Use in Atmospheric Studies. Evaluation Number 14: update of key reactions, Tech. rep., Jet Propulsion Laboratory, California Institute of Technology, Pasadena, California, USA, 2003.

Sander, S. P., Friedl, R. R., Ravishankara, A. R., et al.: Chemical Kinetics and Photochemical Data for Use in Atmospheric Studies, Evaluation Number 15: update of key reactions, Tech. rep., Jet Propulsion Laboratory, California Institute of Technology, Pasadena, California, USA, 2006.

Schofield, R., Kreher, K., Connor, B. J., Johnston, P. V., Thomas, A., Shooter, D., Chipperfield, M. P., Rodgers, C. D., and Mount, G. H.: Retrieved tropospheric and stratospheric BrO columns over Lauder, New Zealand., J. Geophys. Res., 109, D14304, doi:10.1029/2003JD004463, 2004.

Schofield, R., Johnston, P. V., Thomas, A., Kreher, K., Connor, B. J., Wood, S., Shooter, D., Chipperfield, M. P., Richter, A., von Glasow, R., and Rodgers, C. D.: Tropospheric and stratospheric BrO columns over Arrival Heights, Antartica, 2002, J. Geophys. Res., 111, D22310, doi:10.1029/2005JD007022, 2006.

Sheode, N., Sinnhuber, B.-M., Rozanov, A., and Burrows, J. P.: Towards a climatology of stratospheric bromine monoxide from SCIAMACHY limb observations, Atmos. Chem. Phys. Discuss., 6, 6431-6466, 2006, http://www.atmos-chem-physdiscuss.net/6/6431/2006/.

Simpson, W. R., von Glasow, R., Riedel, K., Anderson, P., Ariya, P., Bottenheim, J., Burrows, J., Carpenter, L., Frie $\beta$, U., Goodsite, M.E., Heard, D., Hutterli, M., Jacobi, H.-W., Kaleschke, L., Neff, B., Plane, J., Platt, U., Richter, A., Roscoe, H., Sander, R., Shepson, P., Sodeau, J., Steffen, A., Wagner, T., and Wolff, E.: Halogens and their role in polar boundary-layer ozone depletion, Atmos. Chem. Phys., 7, 4375-4418, 2007, http://www.atmos-chem-phys.net/7/4375/2007/.

Sinnhuber, B.-M., Arlander, D. W., Bovensmann, H., et al.: Comparison of measurements and model calculations of stratospheric bromine monoxide, J. Geophys. Res., 107(D19), 4398 , doi:10.1029//2001JD000940, 2002.

Sinnhuber, B.-M., Rozanov, A., Sheode, N., Afe, O. T., Richter, A., Sinnhuber, M., Wittrock, F., Stiller, G. P., von Clarmann, T., Linden, A., and Burrows, J.P.: Global observations of stratospheric bromine monoxide from SCIAMACHY, Geophys. Res. Lett., 32, L20810, doi:10.1029/2005GL023839, 2005.

Sinnhuber, B.-M. and Folkins, I.: Estimating the contribution of bromoform to stratospheric bromine and its rela- 
tion to dehydration in the tropical tropopause layer, Atmos. Chem. Phys., 6, 4755-4761, 2006, http://www.atmos-chemphys.net/6/4755/2006/.

Sioris, C. E., Kovalenko, L.J., McLinden, C. A., Salawitch, R. J., Van Roozendael, M., Goutail, F., Dorf, M., Pfeilsticker, K., Chance, K., von Savigny, C., Liu, X., Kurosu, T. P., Pommereau, J.-P., Bösch, H., and Frerick, J.: Latitudinal and vertical distribution of bromine monoxide in the lower stratosphere from Scanning Imaging Absorption Spectrometer for Atomspheric Chartography limb scattering measurements, J. Geophys. Res., 111, D14301, doi:10.1029/2005JD006479, 2006.

Soller, R., Nicovich, J. M., and Wine, P. H.: Temperature-dependent rate coefficients for the reactions of $\operatorname{Br}\left({ }^{2} \mathrm{P}_{3 / 2}\right), \mathrm{Cl}\left({ }^{2} \mathrm{P}_{3 / 2}\right)$, and $\mathrm{O}\left({ }^{3} \mathrm{PJ}\right)$ with $\mathrm{BrONO}_{2}$, J. Phys. Chem. A, 105, 1416-1422, 2001.

Solomon, S.: Stratospheric ozone depletion, A review of concepts and history, Rev. Geophys., 37(3), 275-316,1999RG900008, 1999.

Theys, N., Van Roozendael, M., Hendrick, F., Fayt, C., Hermans, C., Baray, J.-L., Goutail, F., Pommereau, J.-P., and De Mazière, M.: Retrieval of stratospheric and tropospheric BrO columns from multi-axis DOAS measurements at Reunion Island $\left(21^{\circ} \mathrm{S}\right.$, 56 ${ }^{\circ}$ E), Atmos. Chem. Phys., 7, 4733-4749, 2007, http://www.atmos-chem-phys.net/7/4733/2007/.

Vandaele, A.-C., Fayt, C., Hendrick, F., Hermans, C., Humbled, F., et al.: An intercomparison campaign of ground-based UV-visible measurements of $\mathrm{NO}_{2}, \mathrm{BrO}$ and $\mathrm{OClO}$ slant columns: Methods of analysis and results for $\mathrm{NO}_{2}$, J. Geophys. Res., 110, D08305, doi:10.1029/2004JD005423, 2005.

Van Roozendael, M., Wagner, T., Richter, A., Pundt, I., Arlander, D., Burrows, J. P., Chipperfield, M., Fayt, C., Johnston, P. V., Lambert, J.-C., Kreher, K., Pfeilsticker, K., Platt, U., Pommereau, J.-P., Sinnhuber, B.-M., Tornkvist, K. K., and Wittrock, F.: Intercomparison of $\mathrm{BrO}$ measurements from ERS-2 GOME, ground-based and balloon platforms, Adv. Space Res., 29, 16611666, 2002.
Vigouroux, C., De Mazière, M., Errera, Q., Chabrillat, S., Mahieu, E., Duchatelet, P., Wood, S., Smale, D., Mikuteit, S., Blumenstock, T., Hase, F., and Jones, N.: Comparisons between groundbased FTIR and MIPAS $\mathrm{N}_{2} \mathrm{O}$ and $\mathrm{HNO}_{3}$ profiles before and after assimilation in BASCOE, Atmos. Chem. Phys., 7, 377-396, 2007, http://www.atmos-chem-phys.net/7/377/2007/.

von Glasow, R., R. von Kuhlmann, M. G. Lawrence, U. Platt, and P. J. Crutzen: Impact of reactive bromine chemistry in the troposphere, Atmos. Chem. Phys., 4, 2481-2497, 2004, http://www.atmos-chem-phys.net/4/2481/2004/.

Wagner, T. and Platt, U.: Satellite mapping of enhanced BrO concentrations in the troposphere, Nature, 395, 486-490, 1998.

Wilmouth, D. M., Hanisco, T. F., Donahue, N. M., and Anderson, J.G.: Fourier transform ultraviolet spectroscopy of the $A_{3 / 2}^{2 \Pi} \leftarrow$ $\mathrm{X}_{3 / 2}^{2 \Pi}$ transition of BrO, J. Phys. Chem. A., 103, 8935-8945, 1999 .

World Meteorological Organization (WMO): Scientific Assessment of Ozone Depletion: 2006, Global ozone research and monitoring project, Chapter 2: Halogenated Very Short-Lived Substances, Rep. 50, Geneva, Switzerland, 2007.

Yang, X., Cox, R. A., Warwick, N. J., Pyle, J. A., Carver, G. D., O'Connor, F. M., and Savage, N. H.: Tropospheric bromine chemistry and its impact on ozone: A model study, J., Geophys. Res., 110, D23311, doi:10.1029/2005JD006244, 2005. 